\title{
Is there a wrong time for a right decision? \\ The impact of the timing of first births and the spacing of second births on women's careers ${ }^{1}$
}

\author{
Gibt es einen falschen Zeitpunkt für eine richtige Entscheidung? \\ Der Einfluss des Timings der Erstgeburt und des Spacings der Zweitgeburt auf \\ die Karrieren von Frauen
}

\begin{abstract}
:
The issue of how to reconcile family and work is particularly relevant in the light of West Germany's institutional and normative framework which has been facilitating mothers of young children to withdraw from the labor market for some years. Though the topic has already been subject to academic debate, the questions remain if and how women's careers are influenced by the way women embed their prevalently two births into their employment biographies as well as if educational groups differ in these effects.

So far, research has mainly focused on the first birth's timing: aspirations to establish firmly on the labor market suggest a postponement of the first birth to some degree. The effect is less obvious for the spacing between first and second births: to avoid a detrimental career discontinuity, women can either choose a short spacing, blocking their periods of unpaid caregiving tightly for a quick and definite occupational return, or space their births widely, intermitting their parental leaves with periods of employment.

Using NEPS data for West German mothers of two, the study finds that compared to career entry, the occupational prestige at age 45 is severely impaired by the period after women's first birth. While this is not affected by a specific timing, higher educated women tend to time their first
\end{abstract}

\section{Zusammenfassung:}

Die Frage nach einer erfolgreichen Vereinbarkeit von Familie und Beruf stellt sich insbesondere in Westdeutschland, wo der institutionelle und normative Rahmen Mütter ermutigt, mehrere Jahre für die Betreuung ihrer Kleinkinder zuhause $\mathrm{zu}$ bleiben. Trotz umfassender Forschung zum Thema blieben bisher die Fragen offen, inwiefern weibliche Karrieren durch die zeitliche Einbettung der überwiegend zwei Geburten in die Erwerbsbiografien beeinflusst werden und ob sich Bildungsgruppen darin unterscheiden.

Bisher konzentrierte sich die Forschung dahingehend vor allem auf das Timing der Erstgeburt: Um sich fest am Arbeitsmarkt zu etablieren scheint eine gewisse Verzögerung der Erstgeburt hilfreich. Bezüglich des Spacings zwischen Erstund Zweitgeburt liegen hingegen zwei Strategien nahe: Entweder bekommen Frauen ihre Kinder kurz nacheinander um danach endgültig an den Arbeitsmarkt zurückzukehren, oder sie nutzen einen langen Abstand zwischen den Kindern für eine berufliche Episode.

Mithilfe eines NEPS-Samples zweifacher Mütter kann die Studie aufzeigen, dass ihr berufliches Prestige zwischen Karriereeinstieg und dem Alter 45 insbesondere von der Episode nach der ersten Geburt beeinträchtigt wird. Obwohl dies nicht durch ein bestimmtes Timing bedingt ist, er-

1 This paper uses data from the National Educational Panel Study (NEPS): Starting Cohort 6 - Adults (Adult Education and Lifelong Learning), doi:10.5157/NEPS:SC6:3.0.1. The NEPS data collection is part of the Framework Program for the Promotion of Empirical Educational Research, funded by the German Federal Ministry of Education and Research and supported by the Federal States. 
births least detrimentally. With regard to the spacing, evidence suggests that only higher educated women can achieve to continue their prestige accumulation, namely by spacing their births very tightly. Lower and intermediately educated women's prestige, in contrast, cannot be impaired considerably by their spacing behavior, unless they decide to return to part-time employment soon after their first birth.

Key words: timing, spacing, occupational prestige, female career weist sich das Timing höher gebildeter Frauen als am wenigsten nachteilig. Für das Spacing zeigt sich, dass nur höher gebildete Frauen nach ihren Betreuungsphasen noch Prestige anhäufen können, so sie denn ihre Kinder im kurzen Abstand zueinander bekommen. Die Prestigeentwicklung von Frauen mit geringerer Bildung hingegen wird nicht wesentlich durch das Spacing vermindert, außer sie entscheiden sich kurz nach der Geburt des ersten Kindes für die Rückkehr in einen Teilzeiterwerb.

Schlagworte: Timing, Spacing, Berufsprestige, weibliche Karriere

\section{Introduction}

It is well-known that a trade-off between work and family is characteristic for women in Germany (Buchholz/Grunow 2006; Grunow 2006; Pfau-Effinger/Smidt 2011). Women's mid-career phase is not as clearly defined as it is for men (Mayer 1991; Lauterbach 1994). This especially applies for West Germany with its long-standing conservative welfare regime (Esping-Andersen 1990) and its rather traditional gender culture (Pfau-Effinger 1996; Falk/Schaeper 2001) which results in a very gender-specific division of labor within families (Schulz/Blossfeld 2006; Grunow et al. 2007). Typical examples for the strong support of a rather traditional gender contract in West Germany include relatively generous maternity leave regulations, tax legislations favoring the male breadwinner or the 1.5 earner model instead of the dual earner model for families, comparatively low early childcare coverage rates, a still mostly half-day oriented kindergarten and schooling system, and strong support for rather traditional gender values. ${ }^{2}$ As a consequence, women's careers in West Germany tend to be marked by employment interruptions as well as by high rates of part-time employment after family formation. Even today, the reconciliation of paid labor and childcare is mostly left to mothers.

A vast body of literature and empirical studies have already addressed the issue of how women in West Germany combine family and work and the effect of family obligations on women's labor market behavior and their employment careers (e.g. Engelbrech 1997; Grunow et al. 2006; Matysiak/Steinmetz 2006; Brose 2008; Aisenbrey et al. 2009; Gangl/ Ziefle 2009). It has been shown that the birth of the first child is the major incision into women's working lives and even occupationally established women draw back quite 'naturally' from the labor market to dedicate themselves to childcare for some years after having made the transition to motherhood (e.g. Blossfeld/Huinink 1991; Reichle 1996; Timm 2006). However, one particular issue that has been underrepresented or even missing altogether in the academic debate is if and how women's careers are influenced by the

2 Although there has been a clear modernization of both the gender culture and welfare state arrangements over the past decades in Germany, changes across time and/or birth cohorts are beyond the scope of this article. Similarly, we will not discuss existing differences between East Germany and West Germany. 
way women embed their birth decisions into their life courses. Precisely, the notion addresses the impact of the timing of the first birth after labor market entry as well as the spacing of childbirths, which, in turn, is the time women allow to elapse after the birth of their first child until having their second child. Since these decisions go along with a specific occupational and childcare behavior, they can be expected to have a major influence on the ways women pursue and succeed in their career. Hence, the central aim of our study is to fill this research gap. Specifically, our analyses aim at answering the following research questions:

- How do mothers' careers develop before and after family formation?

- In what way does women's birth behavior, i.e. their timing of the first births and spacing of the second births, affect women's subsequent careers?

For both of these research questions, we will pay special attention to the question of educational differences. It is well known that women's educational level strongly influences their family planning, especially with regard to timing the birth of their first child (Timm 2006; Kreyenfeld 2007; Brehm 2013). However, the aim of our empirical analyses is to understand if women's timing of the first births and their spacing of the second in their employment careers differently impact their career development. For example, are higher educated women able to reduce their risks of career setbacks with the aid of steeper career developments before their family formation, a later timing of first births, and different spacing of second births?

Our empirical analyses are based on data from the adult cohort of the National Educational Panel Study (NEPS). The NEPS cohort supplies detailed and high-quality longitudinal information on individual life courses for various birth cohorts. Although this dataset also offers information on persons born in East Germany, we only use information of West German women since the East German women in our data have been shaped by a very different gender culture (e.g. Pfau-Effinger 1996; Grunow/Müller 2012). Even 25 years after the fall of the Iron Curtain, the situation of women in East and West Germany is still very different. Modelling intra-German differences as well as the complexity of change after reunification would go beyond the scope of our empirical study. Additionally, we restrict our analyses not only to West German but also to mothers of two because two children are still prevalent in Germany - in both normative and empirical terms (Goldstein/Kreyenfeld 2010). Hence, we will be able to study the impacts exerted by features of both the incisive family formation and the similarly relevant family extension in its predominant pattern in Germany. To measure women's career development, we will use information on their occupational prestige as described by the Standard International Occupational Prestige Scale (SIOPS) (for more information, see research design and methods below). The aim of this specific operationalization is to avoid biases resulting from different sectors and job mobility which may emerge from, e.g., monetary measures.

In our article, we proceed as follows. First, we present the framework of our empirical analyses by first outlining the West German context, previous research findings as well as general theoretical considerations. Based on this discussion, we then elaborate our research design, our data and our methodological approach. In the next step, we present the results of empirical analyses of our study and, thereafter, conclude by summarizing and discussing our findings. 


\section{Theoretical considerations and empirical implications}

\section{Institutional context and previous research results}

In order to understand the relationship between childcare and female employment in West Germany, one has to be aware of the specific family policies that have been influencing women's lives. Generally, following the Christian concept of a conservative welfare state (Esping-Andersen 1990), West Germany has been relying on the principle of subsidiarity in family policy issues. In line with that, the family, including children, is regarded to be one unit that arranges its matters itself. In order to support this self-regulation, the state subsidizes marriages - assuming that this provides the precondition to having children - by enabling a married couple's joint taxation. This instrument facilitates a financial benefit from high income differences between spouses and therefore promotes intra-familial division of labor into housework on the one hand and a gainful employment on the other. Particularly if there are children involved, the state traditionally leaves the care-intensive upbringing of the (young) offspring to the family. Although today public childcare can be provided for almost $20 \%$ of children under the age of three (Institut für Arbeit und Qualifikation 2014), this fairly high rate results from very recent developments that mark a partial change in policy paradigms (e.g. Bujard 2013). For many decades up until the early 2010s, in contrast, the rate of small children that could be cared for institutionally was at 3\% at the most (Matysiak/Steinmetz 2006; Aisenbrey et al. 2009) - a legal claim to public childcare places was only admitted to at least three year olds and only since the mid-1990s. Also, even at times when a vast majority of older children attended kindergartens, most institutions' opening hours required for one parent to care for the offspring from the early afternoon onwards just as, subsequently, by far most schools have been doing, too (ibid.). Normatively, and for a long time even legally ${ }^{3}$, the resulting division of employment vs. household and reproductive tasks has been gender-specific: not parenthood taken as a whole, but specifically motherhood has been assumed to be a demanding responsibility that requires much time and devotion to the offspring. As a result, the majority of families have been living in a family model of a male breadwinner and a female carer that works in a part-time job at most. Female employment has been a given, but only given that there are no children that need to be cared for (Falk/Schaeper 2001; Rosenfeld et al. 2004; Brose 2008).

To protect women against a double burden while facilitating a secured time and room for childcare, West Germany started to introduce labor market policies that ascertain a partly paid parental (and in the beginning even exclusively maternal) leave along with a guarantee to be able to return to their old jobs after less than one year in the late 1970s. In the subsequent decades, these regulations were extended to three years of granted leave with compensatory payments being granted for up to two years. Only rather recent policies of the late 2000 s reversed this development by restricting higher compensatory payments to little more than a year and by explicitly incentivizing the other parent to go on leave as well. Hence, though formally orienting towards women's return to the labor mar-

3 Up until 1977, the Civil Code ruled in $\S 1356$ BGB (1) that a woman was in the first place responsible for housekeeping, any employment was secondary and only permitted if the first could be guaranteed. 
ket after periods of unpaid caregiving, these policies facilitated long and even increasing occupational breaks of mothers.

Economically, women's thereby fostered familial responsibilities have been assumed to occur at the expense of occupational commitment and productivity (Becker 1960, 1981) while a discontinuous employment could even result in a depreciation of mothers' human capital (Becker 1985). While this may not be the case for all women, the productivityabating relation is often also anticipated by employers, at worst resulting in statistical discrimination (Phelps 1972; Arrow 1973). Indeed, research has shown that these policies can work against mothers in the labor market. For West Germany, Gangl and Ziefle (2009) provide evidence for women's weakened position in the labor market due to the higher costs for the employer which they indirectly pass on to mothers, putting all women as potential mothers into an adverse bargaining position (see also Hirschle 2011; Ochsenfeld 2012).

On the whole, the described institutional framework along with mothers' associated bargaining position on the labor market reflects empirically in a low employment rate of mothers with young children in Germany (Matysiak/Steinmetz 2006; Aisenbrey et al. 2009; Berninger 2009; Frodermann et al. 2013). Although studies indicate a gradual rejection of that pattern in younger cohorts, fostered by the increasing importance of part-time jobs (Grunow et al. 2006; Frodermann et al. 2013), historically, extensions of parental leave regulations have been countered quickly by mothers' extension of their time in unpaid childcare (Grunow et al. 2011). Within the legal framework of job security, mothers are entitled to reenter their previous position upon their (part-time) return. Nonetheless, they often choose a job that leads to downwards mobility for the sake of flexibility, the compatibility of family and career, and proximity to home (Engelbrech 1997; Gangl/Ziefle 2009; Hirschle 2011). But even after re-entering the previous job, the employment interruption is likely to result in a considerably lower income, particularly in the long run (Ziefle 2004). This is only partly due to the loss in experience; a large share of the total penalty in terms of wage and career cannot be explained by women's actual labor market behavior (Gangl/Ziefle 2009; Ochsenfeld 2012).

One particularly relevant aspect regarding mothers' careers is their educational level. The higher women's education, the higher the opportunity costs associated with childcare and with the difficulties in combining family and career: highly educated women stand to either lose or gain a lot. As a result, it has been found that one fourth of women with a high schooling degree remain childless whereas this applies to only one eighth of women with a low degree (Aisenbrey et al. 2009; see also Bauer/Jacob 2010). Nonetheless, those highly educated women who decide in favor of children have considerably higher rates of returning to the labor market after childbirth - they even disproportionally refrain from taking parental leave altogether (Matysiak/Steinmetz 2006; Hanel/Riphahn 2011; Drasch 2011; Grunow et al. 2011). Beyond that, they are more likely to return into full-time positions (Matysi$\mathrm{ak} /$ Steinmetz 2006). These quicker returns as well as their higher education itself facilitate higher chances of upward occupational mobility, even as mothers (Aisenbrey et al. 2009).

But what do these deliberations imply to the present study's focal points? How does mothers' career develop in the long term, particularly depending on the period prior to family formation and with special regard to women's educational level? Theoretical and empirical considerations (e.g. Gangl/Ziefle 2009; Aisenbrey et al. 2009; Hirschle 2011; Ochsenfeld 2012) point to a rather minor, possibly even negative career development once women are mothers. Hence, we generally can expect their career developments to be 
primarily dependent on the period prior to family formation and women's achievements during that time. A higher education, however, seems to enable mothers to further climb up the career ladder - due to both their human capital and their birth-related behavior.

The highlighted empirical results convey an impression of the pervasive incision motherhood poses to women's careers. However, they do not allow us to understand the impact exerted by the various specific ways in which women arrange and embed their births into the course of their careers. Hence, it is exactly this issue which our empirical study on West German women will address. Specifically, we aim at understanding the following: how does women's timing of the first birth after labor market entry ${ }^{4}$ affect their subsequent careers? How does the spacing of the family expansion, meaning the time that elapses until women have their second births, impact women's possibilities to secure their career after family formation? How do activities between first and second child birth affect women's career chances? And finally, do the effects of timing and spacing vary by educational level? In other words: Is a specific timing and spacing of births more important for some women's career development than for that of others? However, before assessing these questions empirically, we will first approach them theoretically.

\section{Timing the first birth}

When it comes to the optimal timing of a first birth in the course of a career, there are several opposing theoretical considerations that contribute to a woman's decision. According to a dynamic model of fertility (Gustafsson 2001), the utility of an early birth concerns the precious time as a family: the earlier the child is born the more time will be left to a parent to enjoy with the child or even grandchildren. Most career-related considerations, however, contrast this aspect. As a later timing allows for a longer time of human capital accumulation, childbirth entails a smaller chance of an incisive depreciation, even during longer breaks. Furthermore, as a career can be assumed to develop positively yet diminishingly when approaching its zenith, the expectable subsequent profit becomes smaller, decreasing women's returns and thus their motifs to further invest into human capital: thus a late birth is more beneficial than one earlier in life (see also Miller 2011; Figure 1). In terms of the most profitable timing for a woman's career, it seems that the farthest possible postponement of the first birth decreases its costs. This can be assumed to be particularly true for West Germany. Since family policies regarding parental leaves and public childcare facilitate long breaks of unpaid caregiving and thereby bring occupational aspirations to an almost certain halt, family formation is a very costly decision. A postponement of the first birth would hence enable women to entirely focus on their career for several years and stabilize their occupational position before withdrawing from the labor market for the child's upbringing (Blossfeld/Huinink 1991).

Empirically, however, this clear-cut suggestion does not necessarily encounter evidence, neither internationally nor in West Germany. Some studies do indeed yield results that support a late timing's profitability, emphasizing late mothers' higher labor market in-

4 In many studies, the timing is measured following a life-course perspective, depicting the time since a woman's birth. With regard to this study's subject, however, we choose a more career-oriented approach. 
volvement and income because of the higher respective achievements before birth (Troske/Voicu 2009; Miller 2011). However, other findings suggest that late mothers experience disproportional wage penalties, reinforced by either the shorter time to compensate for the loss in the long term (Putz/Engelhardt in this volume) or by the associated shorter spacing that affects the career negatively due to a longer consecutive leave (Karimi 2014b).

Figure 1: effect of first birth on career, depending on timing

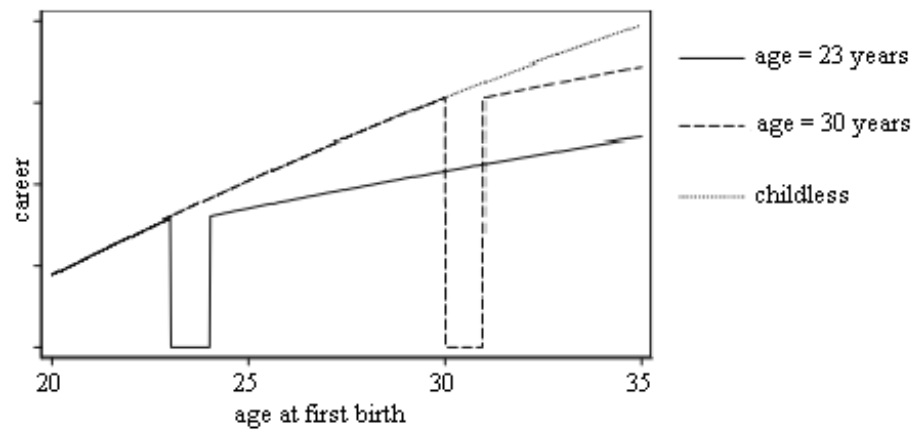

Note: figure abstracted and adjusted from Miller (2011).

All in all, the theoretical implications and the empirical results do not convey a clear picture of the timing's impact on female careers. Instead, they seem to point to an inversely u-shaped effect: at the beginning, the effect of the birth postponement is increasingly positive, yet this relation turns at some point and changes into the opposite. To test if this supposition holds true, we will assess the relationship between women's timing and their careers empirically.

While these considerations address the timing's overall impact, we can assume educational differences in the timing's effect on the career. Concerning these, however, no precise indication for assumptions could be extracted from previous work. What has been established is a longer postponement of births of higher educated women, partly because of their greater range of (occupational) opportunities (e.g. Weber 2004; Timm 2006; Bauer/ Jacob 2010), partly because of their higher aspirations regarding the child's education and wellbeing for which they aspire to meet the perceived material requirements (Gustafsson 2001). This already indicates that higher educated women plan their births more thoughtfully, thoroughly weighing both their high opportunity costs and their chances to combine work and family (Beets 2011), especially in the light of insufficient institutional opportunities to sustain their previous pursuit of career. As a result, we can expect higher educated women's timing to have a more positive effect on their career than what applies to less educated women - possibly even independent from the actual timing.

\section{Spacing the second birth}

As has already been implied, the spacing between the first and the second birth is similarly relevant for a mother's career. A major influencing factor in this regard is mothers' 
time allocated to childcare, be it in two consecutive parental leaves or in a subsequence of breaks that are intermitted by episodes of employment.

Theoretically, a long spacing is assumed to allow for a better balanced use of opportunities and alternatives to childcare, enabling occupational continuity and smoothing consumption by shortening the time women spend away from the labor market (Newman 1983; Troske/Voicu 2009). Nonetheless, the cost effectiveness of children is assumed to increase strongly by a second child (Newman 1983): while the transition to the first child is a major incision into a woman's career, the second child is supposed to be not much of an additional hindrance as many arrangements have already been made.

Presumably, the Swedish government has been following this thought when it decided to pay a speed premium to first-time mothers in order to support a quick second birth before reentering the labor market. Nonetheless, Karimi (2014a) was able to show with a Swedish sample, that a longer spacing is more and increasingly beneficial for women's income as it enables them to return to the labor market between births - which results in a higher and profitable attachment to the labor market (see also Miller/Xiao 1999; Troske/ Voicu 2009). West Germany's institutional framework, however, has been setting considerable constraints to such a quick return to the labor market after the first birth. The structural and financial incentives to go on parental leave for up to three years on the one hand and the lack in (all-day) public childcare for young children on the other hand made women withdraw from the labor market for several years after their first birth. To successfully return to the labor market before giving birth to their second child, mothers would have to space their two children very widely, bringing many years of age difference between the siblings. Firstly, such a long spacing and a labor market return in the meantime can be presumed to reduce the cost effectiveness usually associated with a second child. Secondly, it can be supposed that not only one but two occupational breaks of several years would impair a woman's career substantially. As a result, it seems reasonable for West German women to space their births shortly in order to return rather quick and definitely after only one occupational break, merged for both children.

Nonetheless, the scarce national and international evidence points at the profitability of a long spacing that is intermitted by episodes of employment, particularly when these are pursued full-time. Especially in light of an easier access to part-time jobs in the German context, a full-time employment between births indicates a considerably higher occupational commitment (Frodermann et al. 2013; Hipp/Stuth 2013). Thereby it facilitates the continuity of tasks and experience and protects better against dequalification, downward mobility and, hence, income loss (Vogel 2009). Assumedly, this also mirrors for prestige measures in the data: mothers' chances to maintain or even raise their prestige after having children can be expected to be highest for those who space their births widely in order to return to the labor market - particularly if they show high occupational commitment by working full-time.

When relocating the focus from the spacing's overall impact of women's careers to educational differences, however, evidence is again rather scanty. In terms of the spacing itself, children are assumed to benefit from a longer spacing (Newman 1983) as it decreases siblings' direct competition for parental resources and therefore leaves more time to allocate to each child's individual fostering. This can be expected to be in accordance with the wishes of highly educated women in particular. Nonetheless, higher educated women have been found to space their births more shortly. One major reason given for this behavior is a pro- 
cess of self-selection: in light of their high opportunity costs, highly educated first-time mothers prove a relatively high family orientation that also leads to a quick family expansion (Kreyenfeld 2002; Bernhard/Kurz 2007; Brose 2008). Again, however, it remains as yet unclear what these results imply for the spacing's impact on differently educated women's careers. In line with the previous argument regarding the timing, we assume a particularly high reflective faculty in higher educated women who consider the compatibility of family and career as well as opportunity costs more thoughtfully (Beets 2011). As a result, a longer spacing in order to enable beneficial occupational continuity would be an especially attractive and valuable instrument for them, particularly since higher educated women have been found to reenter the labor market more quickly after their first birth, to be more likely to return into full-time employment, or to waive their entitlement to parental leave altogether (Matysiak/Steinmetz 2006; Hanel/Riphahn 2011; Drasch 2011; Grunow et al. 2011). However, their spacing has been found to be rather short. This behavior could arise from a rationality that strives for a relatively short occupational interruption for both children in quick succession - in order to return to the labor market quickly, definitely and successfully. As both assumptions appear valid, they have to be collocated in our analysis.

To follow up the posed research questions and elaborated hypotheses, we approach the topic empirically. In order to do so, the following section introduces the underlying analytic design, the chosen data as well as the methods to elaborate on the issue.

\section{Research design, data and methods}

\section{Research design}

The aim of our empirical analyses is to understand if and how West German women's careers are influenced by their birth behavior, specifically the timing of the first birth and the spacing of the second one. To model women's career development across time, we observe mothers of two at different time points in their careers. We assess their occupational prestige, described by the Standard International Occupational Prestige Scale SIOPS (Treiman 1975), at labor market entry, one year before their first birth, and finally at the age of 45 . We decided for the age of 45 as our observation's last point in time for several reasons: firstly, additional analyses with our sample have shown that if women have not returned to employment until this age, they barely return thereafter. Hence, our analyses are able to capture those mothers who intend to combine family and work. Secondly, research has shown that the age of 45 usually marks the high point in individuals' careers. Up to that age, the most and most important steps on the career ladder have been taken and the approaching retirement yields the danger that additional investments may not pay off anymore (Schippers 2011). Thirdly, women's fertility usually comes to a standstill at about the age of 45 . Therefore, most women have completed their family formation and expansion by that point.

To approach our research issue empirically, we address them step by step, starting off with the overall development of women's prestige before family formation and across the course of their career. First, descriptive methods of analysis help us to reveal the career developments overall and by educational groups. With the aid of linear regression, we then follow up the relationships and underlying mechanisms across the course of women's career in 
more detail. Following up the impact of women's specific birth behavior on their career in a second step, we extend the elaborated models by women's timing of first births and spacing of second births and their associated activities in between. To address the question of education-specific effects, we introduce interaction terms between education and birth behavior. However, as particularly the last step can be expected to raise the complexity of the model's propositions beyond easy comprehensibility, we will, at last, simulate the findings' specific implications to the development of women's long-term careers, based on the obtained results. Since the youngest women hint best at more recent developments that may have taken place and hence carry a particular contentual weight, we will pay special regard to the youngest birth cohort in most of our analyses. Firstly, we do so by adducing them as reference in our multivariate estimations. Secondly, we adjust our simulations to the youngest cohort by drawing from the results estimated before as well as applying the cohort's specific prestige measures (see section 4). This approach is supported by the sample's composition: most women were born during the most recent observable years as can be examined in Table 2 .

\section{Data}

Our empirical analysis is based on data from the German National Educational Panel Study (NEPS) (Blossfeld et al. 2011). Adapting a precursive study in 2007/08, the survey has been collecting detailed retrospective data at every person's first interview and panel data on a yearly basis since 2009/10. The relevant adult sample with cohorts between 1944 and 1986 consists of altogether 11932 people who have been surveyed in computer-assisted telephone (CATI) and personal interviews (CAPI) by the latest considered panel wave in 2011/12.

Though the NEPS data also offers information for persons born in East Germany, we restrict our analyses to West German women because the employment behavior of East and West German women is even today hardly comparable. The East German gender culture is far more modern (e.g. Pfau-Effinger 1996), also childcare patterns vary strongly. Modeling such complex intra-German differences as well as the complexity of change after reunification would go beyond the scope of our empirical study. Because of the specific research interest of our study, which is to analyze the effect of family formation and expansion on women's careers, and because two children are normatively and empirically still the prevalent family model, we additionally restrict our sample to mothers of two and biological motherhood only.

To assess these women's career development, we observe women at three time points of their career, precisely at career entry, one year before the birth of their first child and finally at the age of $45^{5}$. This means we exclude women that were unemployed or inactive, e.g. as housekeepers, at any of these time points. We are aware that, based on this sample definition, we are not able to picture the lives of all women and mothers. However, as our specific research interest is in studying the effects of family formation and expansion on women's career developments, we have to restrict our analyses 'by definition'

5 As the prerequisite for the women in our sample is to have already reached the age of 45 at the last interview, we restrict our sample to the women born between 1944 and 1966 . We will use the dummies for cohorts in our models mainly as control variables and will not interpret these effects as the focus of our study is not on cohort changes. 
to women who indeed combined family and employment. We also exclude women that had their first child prior to their career entry, which is a rare event ${ }^{6}$. Additionally, we exclude those very occasional cases with an implausible short spacing between the two births of less than nine months as well as mothers of multiples. Based on these definitions, our sample comprises 570 women with two (biological) children which represent approximately $70 \%{ }^{7}$ of the women with two children in our dataset.

\section{Method}

In order to get an impression of women's career developments and their influencing factors, we apply both descriptive and multivariate methods. First, after a very basic descriptive analysis of the sample's mean prestige developments, we aim to describe the interrelation of women's career steps before and after family formation, overall and across educational groups. To do so, we cluster our women along their prestige differences between the beginning of their career and the first cut-off one year before the first birth as well as between the latter and their prestige at age 45 .

In a second step, we aim at examining women's career development as a function of the timing of their first births, the spacing of their second births, the related activities, and their education. Specifically, we do so by calculating a robust stepwise OLS on the difference between their occupational prestige at career entry and their prestige at the age of 45 . In choosing this method, we take advantage of the opportunity to model the effects induced by the full employment and family biography up to the relevant age. As most of the independent variables describe the length of women's time in either a familial (childless, with only one child) or an activity state (e.g., employment, unemployment, unpaid caregiving before birth timing or during birth spacing), they can enter the model as continuous variables.

Thirdly, we aim to illustrate ideal type careers and prestige developments by performing simulations. To do so, we apply the estimated regression effects to meaningful combinations regarding birth behavior, associated activities and women's educational level. The pursuit of these simulations is to visualize the results' implications to women's careers and the impact of embedded family- and work-related decisions.

The occupational prestige is obtained from NEPS's computation of SIOPS-08, the current edition of the Standard International Occupational Prestige Scale (cf. Treiman 1975). The scale integrates public prestige evaluations on an international average, guided by ISCO- $08^{\prime} \mathrm{s}^{8}$ occupational unit groups. Though the score actually ranges from 0 to 100 , jobs realistically cluster between 20 and 80 . Paying tribute to this non-ratio scale, we center the prestige at career entry at the sample's mean value. The further transfer of the SIOPS measure to the central career variables as well as the operationalization of the other relevant factors are summarized in Table 1.

\footnotetext{
Approximately four percent have their first child prior to their first job.

7 The share of women does not vary considerably by cohort and only slightly by educational level with a higher percentage of intermediately educated women.

8 International Standard Classification of Occupation by the International Labour Organization (ILO)
} 
Table 1: operationalization of relevant variables to women's career development

\begin{tabular}{|c|c|}
\hline prestige at career entry & $\begin{array}{l}\text { SIOPS of most prestigious job at labor market entry, } \\
\text { centered around the sample's mean }\end{array}$ \\
\hline $\begin{array}{l}\text { prestige development before } \\
\text { the first birth }\end{array}$ & $\begin{array}{l}\text { difference between most prestigious jobs' SIOPS at labor market entry and one year before } \\
\text { the timing of the first birth [if the first birth is timed less than one year after career entry, we } \\
\text { consider the first job's SIOPS] }\end{array}$ \\
\hline $\begin{array}{l}\text { prestige development across } \\
\text { the career }\end{array}$ & difference between most prestigious jobs' SIOPS at labor market entry and at the age of 45 \\
\hline educational level & $\begin{array}{l}\text { general and academic school leaving degrees: } \\
\text { no or lower secondary degree (Haupt-Nolksschulabschluss) } \\
\text { middle secondary degree (Mittlere Reife) } \\
\text { upper secondary degree (Abitur) } \\
\text { tertiary degree (Fachhochschul-/Universitätsabschluss) }\end{array}$ \\
\hline control: cohorts & $\begin{array}{l}\text { aggregated birth cohorts: } \\
1944 \text { to } 1949 \\
1950 \text { to } 1954 \\
1955 \text { to } 1959 \\
1960 \text { to } 1966\end{array}$ \\
\hline timing & elapsed time between labor market entry and the first birth \\
\hline spacing & elapsed time between the first birth and the second birth \\
\hline $\begin{array}{l}\text { activities before the first } \\
\text { birth/during spacing: }\end{array}$ & $\begin{array}{l}\text { duration variables calculated from monthly event data between labor market entry and the } \\
\text { first birth or between the first birth and the second birth }\end{array}$ \\
\hline employment & $\begin{array}{l}\text { episodes of one or more occupations, net of interruptions due to parental leaves yet includ- } \\
\text { ing occupations that are taken up during parental leave }\end{array}$ \\
\hline full-time employment & $\begin{array}{l}\text { employment episode with working hours that add up to the equivalent to one employment } \\
\text { with reportedly more than part-time or full-time employment }\end{array}$ \\
\hline part-time ${ }^{9}$ employment & $\begin{array}{l}\text { employment episodes with working hours that add up to the equivalent to one employment } \\
\text { with reportedly less than part-time or part-time employment }\end{array}$ \\
\hline other/flexible employment & $\begin{array}{l}\text { episodes of employments in which at least one job is reported to have flexible hours or all } \\
\text { jobs are reported to need no time effort at all }\end{array}$ \\
\hline unpaid caregiving & episodes of parental leave or housekeeping $\quad$ \\
\hline unemployment & episodes of unemployment \\
\hline education & episodes of education in school, university or vocational training \\
\hline other & episodes of miscellaneous activities \\
\hline
\end{tabular}

To provide an overview of the variables' numerical composition, Table 2 conveys detailed descriptive statistics. As can be seen, the sample's employment pattern is characterized by high levels of full-time employment before the first births: only a minority participated in other activities, e.g. housekeeping, often only for a few months. The employment pattern between the births of the first and the second child is influenced by the selectivity of our sample which, in turn, results from our examination of women who combine family and employment. Hence, these women participate disproportionally in (full-time) employment.

9 Regarding the working hours, the NEPS dataset only contains information at the beginning as well as at the end of an employment. While this only tells us if women changed their working hours but does not offer any indication as to when they did it, we assume this to happen in the wake of a birth and the normative responsibilities related to it. 
Table 2: descriptive statistics to relevant variables to women's career development

\begin{tabular}{|c|c|c|c|c|c|}
\hline \multicolumn{3}{|l|}{ occupational prestige $^{10}$} & \multirow{2}{*}{$\frac{\text { mean }}{44,8}$} & \multicolumn{2}{|c|}{ std. dev. } \\
\hline \multicolumn{3}{|l|}{ prestige at career entry } & & \multicolumn{2}{|c|}{10,5} \\
\hline \multicolumn{3}{|c|}{ prestige one year before first birth } & 46,1 & \multicolumn{2}{|c|}{10,0} \\
\hline \multicolumn{3}{|c|}{ prestige at age 45} & 44,9 & \multicolumn{2}{|c|}{11,7} \\
\hline educational level & $\mathbf{N}$ & $\%$ & control: cohorts & $\mathbf{N}$ & $\%$ \\
\hline $\begin{array}{l}\text { no or } \\
\text { lower secondary degree }\end{array}$ & 169 & $29,7 \%$ & $1944-49$ & 96 & $16,8 \%$ \\
\hline middle secondary degree & 249 & $43,7 \%$ & $1950-54$ & 90 & $15,8 \%$ \\
\hline upper secondary degree & 63 & $11,1 \%$ & $1955-59$ & 148 & $26,0 \%$ \\
\hline tertiary degree & 89 & $15,6 \%$ & $1960-66$ & 236 & $41,4 \%$ \\
\hline \multicolumn{2}{|l|}{ total } & $100 \%$ & total & \multicolumn{2}{|r|}{$100 \%$} \\
\hline \multicolumn{3}{|l|}{ birth behavior } & mean & \multicolumn{2}{|c|}{ std. dev. } \\
\hline \multicolumn{3}{|l|}{ timing } & 6,8 & \multicolumn{2}{|c|}{3,7} \\
\hline \multicolumn{3}{|l|}{ spacing } & 3,8 & \multicolumn{2}{|c|}{2,4} \\
\hline activities $^{11}$ & $\mathbf{N}$ & $\%$ & & $\mathbf{N}$ & $\%$ \\
\hline \multicolumn{3}{|l|}{ before first birth: } & \multicolumn{3}{|l|}{ during spacing: } \\
\hline employment & 570 & $100,0 \%$ & employment & 384 & $67,4 \%$ \\
\hline of which: & & & of which: & & \\
\hline full-time & 532 & $93,3 \%$ & full-time & 235 & $61,2 \%$ \\
\hline part-time & 52 & $9,1 \%$ & part-time & 161 & $41,9 \%$ \\
\hline other/flexible & 49 & $8,6 \%$ & other/flexible & 31 & $8,1 \%$ \\
\hline unpaid caregiving & 87 & $15,3 \%$ & unpaid caregiving & 436 & $76,5 \%$ \\
\hline unemployment & 58 & $10,2 \%$ & unemployment & 61 & $10,7 \%$ \\
\hline education & 68 & $11,9 \%$ & education & 14 & $2,5 \%$ \\
\hline other & 39 & $6,8 \%$ & other & 42 & $7,4 \%$ \\
\hline$N=$ & & & & & 570 \\
\hline
\end{tabular}

\section{Results}

\section{Women's career before and after the first birth's timing}

Our first research question aims at systematically reconstructing West German women's career development across their career as well as in relation to their development prior to family formation. We expect the first birth to be a major incision into women's careers, resulting in an only slightly positive or even negative prestige development after family formation. Instead, we expect the period before family formation to play the major part in women's overall career development.

10 The prestige measures are reported in absolute values only, not as centered figures or as differences.

11 The percentages describe the shares of women who participated in specific activities during the observed periods. Since many women participate in different consecutive activities during these periods, the percentages sum up to well above $100 \%$. 
We approach this issue by starting off with a broad examination of women's careers. To do so, Table 3 provides a first impression of our sample's prestige at career entry (i.e. before the observed women have had two children), their development before family formation (that is, one year before the birth of the first child) and the prestige they attain by the age of 45 in relation to their prestige at entry. The table reveals the mean values of both the absolute prestige at career entry and the developmental career measures. Additionally, it symbolizes the shares of women's prestige developments before the first births as well as across their career. Positive progresses are indicated by upward arrows, career descents are reported next to downward arrows, and the shares in which comparing the prestige scores of the respective two points in time do not yield any differences are shown above horizontal arrows ${ }^{12}$.

Table 3: women's occupational prestige and prestige development

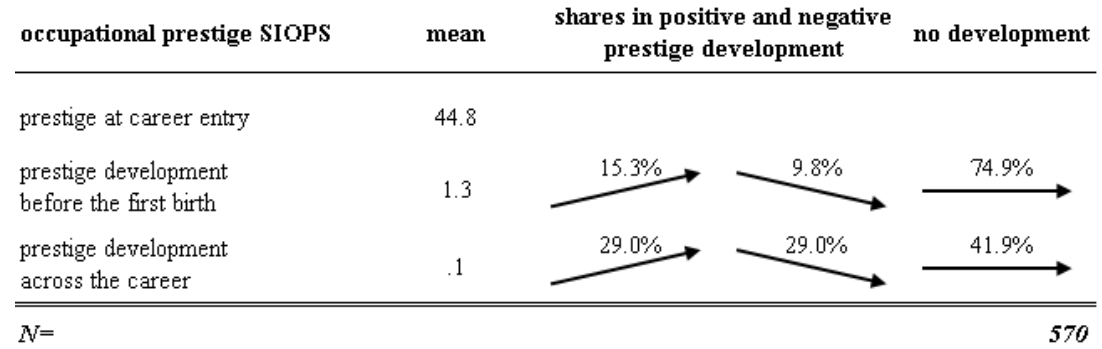

Note: prestige at career entry reported in absolute values, not centered.

On average, the sampled women first enter into a job with a prestige score of almost 45 . Such a prestige is, for example, assigned to nursing associate professionals, retail managers, and car mechanics. Upon their first births' timing, only about $25 \%$ of our women show any prestige development compared to their prestige at career entry. Of those that do, however, the majority - that is $15.3 \%$ in absolute values - report a positive career progression. Additional yet unreported analyses yield that these 'high flyers' gain an average of 13.9 prestige points, lifting them into prestige scores that are assigned to, e.g., dispensing opticians, therapeutic equipment technicians and ship engineers. The $9.8 \%$ of women that report prestige impairment before their first births, in contrast, lose a mean of 8.6 points, resulting in a prestige that is similar to that of hotel managers, library clerks and blacksmiths. The higher share of positive prestige developments raises the overall mean to a prestige enhancement of 1.3.

At the peak of mothers' career at age 45, the results yield that the share of women that do not show any career development has decreased remarkably to $41.9 \%$. Hence, the share of women that report prestige changes rises considerably after family formation, suggesting that the occupational episode after transiting to motherhood is, on average, much more important to mothers' careers than expected. In line with our assumptions, though, the period after family formation is much more characterized by negative prestige developments, reflected by the fact that the prestige developments before family formation - which are positive on average - cannot hold their ground. The shares and developmental magnitudes of

12 The premise of comparing prestige scores at two points in time involves the risk of underestimating developments that again reverse in the course of time. 
those with positive and negative prestige developments across their careers balance each other (each amounting to $29 \%$ ). Unreported analyses show that both groups develop by between eleven and twelve prestige points on average. Comparing these results to the developments before family formation suggests that, on average, most prestige enhancements women achieve before having their first child disappear after their transition to motherhood.

In addition to this overall picture, Table 4 approaches our research question concerning educational differences in women's career development. Our assumption was that a higher education smoothens the career development before and after family formation by enabling higher educated women to even climb up the career ladder once they are mothers. A comparison between the mean prestige developments of the period before the first birth to those across the long-term career does yield some support to that assumption: the values become increasingly positive in both periods the higher women's education is and the average loss of the attained prestige after family formation is only slightly smaller for higher educated women.

The total values in the two aforementioned tables are, however, not able to convey an impression of if and how this subsequent balancing is related to the development prior to family formation in the individual cases. To follow up this question, Figure 2 provides a first overview of the developments' interrelations. To do so, it illustrates - again with the aid of upward, downward and horizontal arrows - women's shares of prestige developments before family formation and, proceeding from these, their further development after their first births. Although these shares do give an impression of the proportional relevance of respective developments, they do not convey the developments' exact magnitudes.

Table 4: women's occupational prestige and prestige development by educational group ${ }^{13}$

\begin{tabular}{lcccc}
\hline & \multicolumn{4}{c}{ means } \\
\cline { 2 - 5 } occupational prestige SIOPS & $\begin{array}{c}\text { no or lower } \\
\text { secondary education }\end{array}$ & $\begin{array}{c}\text { middle second- upper secondary } \\
\text { ary education }\end{array}$ & $\begin{array}{c}\text { education } \\
\text { education }\end{array}$ \\
\hline prestige at career entry & 40.5 & 43.8 & 45.8 & 55.2 \\
prestige development before the first birth & .0 & 1.5 & 1.8 & 2.7 \\
prestige development across the career & -1.3 & .3 & 1.1 & 1.6 \\
\hline $\mathbf{N =}$ & & & $\mathbf{5 7 0}$ \\
\hline
\end{tabular}

Note: prestige at career entry reported in absolute values, not centered.

As already could be seen in Table 3, Figure 2 again yields that the vast majority of women show no prestige development at all before family formation, and most of the remaining part report positive career developments. Yet, these paths already taken are not necessarily reflected in the occupational period after the first births. During this period, all three groups those with positive, negative and null development - report primarily stability. Beyond that, however, it seems that the more positive the development was before transiting to motherhood, the higher are the risks of losing prestige afterwards: among those women that gained

13 For the youngest cohort, the women we refer to most in our analyses, prestige measures are slightly different. Particularly, this applies to the prestige at career entry: for women with no or lower secondary education, it averages to 36.61 (e.g. library clerks, market salespersons), for those with intermediate education to 44.2 (e.g. nursing associate professionals, keyboard operators), for those with upper secondary education to 46.28 (e.g. midwifery professionals, insurance representatives), and for tertiary educated women to 53.54 (e.g. social work professionals, archivists). 
$(15.3 \%)$ or did not report any development before family formation $(74.9 \%)$, more women forfeit occupational prestige afterwards (6.0\% resp. 20.4\%) than (further) accumulating it ( $2.8 \%$ resp. $15.1 \%)$. Of those that lost prestige between career entry and first birth, instead, the figures prove the contrary ( $1.6 \%$ vs. $3.7 \%)$. Hence, it does not indicate that the achievements before the first birth guarantee a further climbing up on the career ladder or even an ensured prestigious position, but it seems that the transition to motherhood introduces new insecurities and possibly penalties. This also reflects in the, in sum, higher share of women that report negative prestige developments after the first births $\left(27.9 \%{ }^{14}\right)$ than positive ones $\left(21.6 \%{ }^{15}\right)$ - quite the opposite picture compared to the developmental distribution before.

In addition to this overall picture, Figure 2 follows up the educational differences in Table 4 that yielded some support to the assumption of a less severe impact of the first birth on higher educated women's career. The figure shows that there are major differences between educational groups. During the period before family formation, higher educated women succeed distinctly more often in terms of prestige - even though educational groups do not vary considerably in their timing of first births: for all groups approximately seven years ${ }^{16}$ pass after career entry. Altogether, a positive career emerges for $20.6 \%$ to $22.5 \%$ of women with upper secondary or tertiary education prior to their first birth - compared to a respective figure of only $10.7 \%$ for low educated women. Additionally, a higher education helps to at least maintain these achievements, even during motherhood: though the chances of further accumulating prestige is universally low across educational groups - only between $1.8 \%$ and $4.8 \%$ of women manage to gain consistently across their career - the shares of women that forfeit their before acquired prestige after their first births (between 5.9\% and 6.4\%) does not grow proportionally with the share of women who are successful before their first births (between $10.7 \%$ and $22.5 \%$ ). Hence, higher education seems to facilitate both a prestige gain before family formation and the ability to secure this achievement beyond the transition to motherhood.

Besides that, particularly women with tertiary education seem to be by far least likely to show no prestige development before family formation at all: in contrast to the other educational groups - in which between $74.0 \%$ and $79.1 \%$ report a null development - only $65.2 \%$ of tertiary educated women display prestige stability. Apparently, for highly educated women, the episode before family formation is very rich in occupational opportunities and thus mobility. Those that did not seize these opportunities, however, seem to have considerably lower chances of making up for the omission after becoming mothers: only very few women $(4.5 \%)$ manage to gain prestige after their first births even though they did not report any development before.

Subsequent to the highly educated women's eventful episodes before their first births, however, these women show the highest share of prestige-neutral career developments: in sum, $65.2 \%{ }^{17}$ of women with tertiary education do not report any (further) development after transiting to motherhood, in contrast to $53.4 \%$ and $55.6 \%{ }^{18}$, respectively, of women

$14 \quad 6.0 \%+20.4 \%+1.6 \%$

$15 \quad 2.8 \%+15.1 \%+3.7 \%$

16 Additional yet unreported analyses yield that the youngest cohort's timing ranges between 6.74 (upper secondary education) and 7.18 years (middle secondary education).

$17 \quad 12.4 \%+46.1 \%+6.7 \%$

$18 \quad 6.0 \%+44.2 \%+3.2 \%$ resp. $9.5 \%+44.4 \%+1.6 \%$ 
with middle or upper secondary education. Low educated women, however, constitute a distinct exception in this respect: there is no registered prestige change after the first births for as little as $36.7 \%{ }^{19}$. Apparently, the risks and chances to their prestige seem to be largest after family formation - while the risks seem to prevail. In line with our supposition, this suggests that lower educated women are penalized the most for their motherhood, not only in terms of their expectable prestige but seemingly also with regard to the reliability of their jobs. The highly educated, in contrast, appear to attain a long-term occupational security before their first births which they can rely upon as mothers.

These descriptive results provide a first interesting insight into prestige developments, particularly with regard to the differences across educational groups. To get an even deeper understanding of West German women's career developments before and after their first births, we assess the impactful factors multivariately by regressing prestige, education and controlling measures to the prestige development between career entry and the career's high point at age 45 in Table 3.

In a first step, we further concentrate on how mothers' careers develop overall, particularly in relation to their career before family formation. With regard to the shares of women whose prestige develops positively, descriptive analyses have shown that the overall proportion of women that report prestige developments rise considerably after family formation. Also, while the shares of positive developments outnumber those of negative ones during the period before the first births, the opposite is true for the period afterwards. However, no specific pattern shows behind these developments: the results did not convey specific paths taken before the first births of which women keep track afterwards. To examine the magnitudes of developments beyond their shares, Model 1 estimates the impact of both the mean-centered prestige at career entry and its subsequent development until just before a woman's first birth.

Assuming a zero development for the latter, which has proven to reflect the career of almost $75 \%$ of women, shows that the higher the occupational prestige is at career entry, the smaller is mothers' career enhancement by age 45 . At first sight, this seems natural as the prestige score is constrained by lower and upper bounds which offer limited opportunities to occupational ascents and descents. However, the constant suggests that already entering the career at a prestige score of the average 44.8 leads on to a slight loss across the career. Of every additional prestige point that women secure at career entry, one quarter will be lost by the age 45. A positive career prior to the first birth, instead, raises the lifelong career gain by .62 per prestige point. This means that of the prestige women manage to gain before forming a family, more than one third will be lost after they have become mothers of two. Hence, gaining prestige before the first birth does not guarantee its preservation into motherhood neither does it indicate an ongoing prestige gain. Also, glancing at the model's power to explain the variance, it becomes apparent that those two variables account for as much as $32 \%$ of women's variance in their career at age 45 - an indeed sizeable impact. It supports the high relevance of the period before the first child for women's long-term career - yet still, a considerably greater role seems to be left to other factors, possibly the period after family formation.

$193.0 \%+27.2 \%+6.5 \%$ 
Figure 2: development of occupational prestige before and after timing in total and by educational level
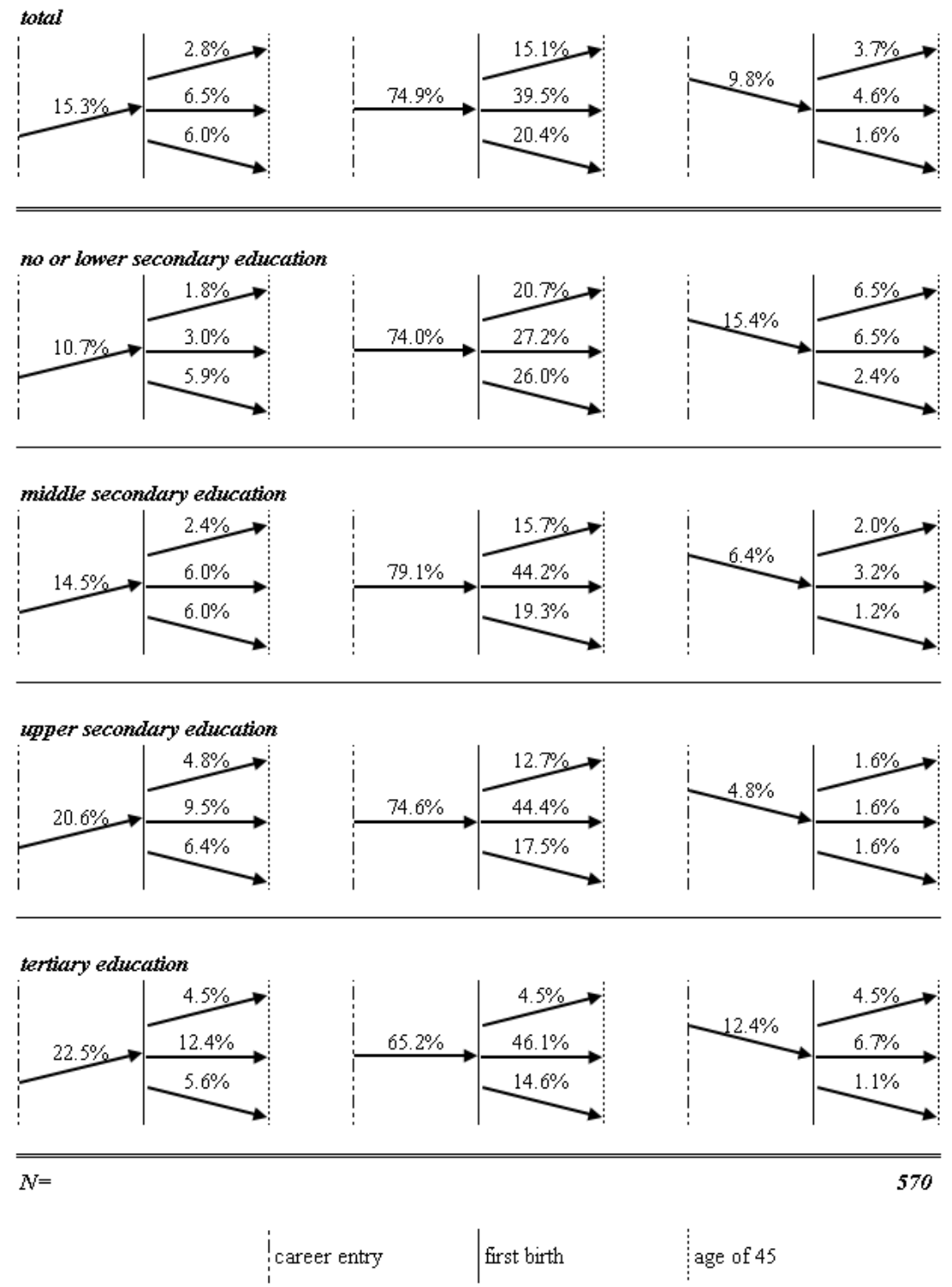

The second part of our research question regarding women's career development before and after the first birth concerns education-specific differences. Preliminary analyses have suggested that the relevance of the occupational period before family formation varies by educational group: greater shares of highly educated women gain during that period and manage to secure their achievements beyond their transition to motherhood - while at the same time lower educated women seem to be confronted with an increased insecurity re- 
sulting from their first birth. To get a deeper understanding of the processes, in Models 2 to 4 we pay special attention to the already evinced educational differences.

In a first step, we consider the further prestige development across educational groups, controlled for cohort effects (Model 2). For the time after family formation, no or a lower secondary education reduces the expectable prestige gain after family formation in comparison to intermediately educated women - despite the high amount of changes. Mothers' upper secondary education, in contrast, does not raise the expectable prestige gain above that of the reference category, even though descriptive analyses yielded high chances of prestige enhancement before the first births. Instead, only a tertiary degree pays off across the career as a mother - presumably, this is primarily because they manage to maintain the prestige they have attained before first births better than other educational groups. Nonetheless, the educational pay-off is enormous and further adds to the higher prestige of women with tertiary education at career entry: in the youngest cohort, it exceeds intermediately educated women's entry prestige by a mean of more than nine points.

Beyond these differences, however, education-specific impacts of attainments before family formation are rather complex in nature. Precisely, in Model 3 there is some marginally significant ${ }^{20}$ support to the result that women with tertiary education benefit more from prestige gained between career entry and their first births: they seem to be able to maintain an additional one fifth of every gained prestige point - given that the prestige at career entry and the gained prestige before the first birth are similar to that of intermediately educated women. As this is hardly the case, however, Model 4 proves that there is even more to this picture: an education-specific interaction of prestige at career entry and prestige development prior to timing suggests a slightly smaller gain from the latter for both women with no or lower secondary and tertiary education. While the magnitude seems rather small at first sight, applying the very different means of the youngest cohort's prestige measures for the concerning educational groups (see section 3) sheds light upon the interaction's relevance. Starting from their considerably lower average prestige at career entry, mothers with no or lower secondary education are influenced considerably more by the prestige they gain or forfeit between career entry and their first birth: every additional prestige point predicts two thirds of a prestige point at the age of 45 . While this means they are considerably more prone to continue losing prestige as mothers if they have taken that path before their transition to motherhood, it also implies that they would profit remarkably from the prestige they manage to attain during that period. Mothers with tertiary education, in contrast, start off at a considerably higher prestige level at career entry and have been shown to have a period before their transition to motherhood that is considerably more eventful, presumably because of a greater variety of opportunities. After transiting to motherhood, however, the prestige gained or forfeited during that time has fairly little influence on their long-term prestige development; it seems that their career is stabilized.

These results emphasize the insecurity lower educated women face on the labor market once they have become mothers: they are influenced heavily from their attainments or omissions before family formation. The higher women's education and hence the higher their prestige and additional attainment before family formation is, the smaller is this influence, suggesting an increasingly stabilized career once these women are mothers.

$20 \mathrm{p}=.11$ 
The depicted analyses aimed at systematically reconstructing West German women's career development in relation to the period before the first birth. Secondly, they intended to answer the question of education-specific differences in these developments. The results have shown that the period after family formation is indeed fairly detrimental to women's prestige; the on average positive attainments before the transition to motherhood do not ensure stability. This seems to be particularly true for women with no or lower secondary education: the data suggests that they face the highest amount of insecurity as mothers. Although they show, on average, very little prestige development before family formation, their attainments as well as omissions influence their long-term career considerably. Highly educated women, in contrast, often profit from an episode of many occupational opportunities between career entry and their first birth: they on average manage to attain prestige additionally to their high prestige at career entry. After their transition to motherhood, these attainments seem to offer long-term occupational security.

But how do these careers depend on women's birth behavior concerning their first births' timing as well as their second births' spacing? What role do the activities play, especially during the spacing? And in what way are the elaborated educational differences due to education-specific timing and spacing decisions? In the next step, we follow up these questions by multivariately controlling for their impact on women's careers.

Table 5: impact of previous prestige measures and education on prestige at age 45

\begin{tabular}{|c|c|c|c|c|}
\hline & 1 & 2 & 3 & 4 \\
\hline & b & b & b & b \\
\hline prestige at career entry & $-.25^{\star *}$ & $-.40^{* *}$ & $-.41^{* *}$ & $-.40^{* *}$ \\
\hline prestige development before the first birth & $.62^{* *}$ & $.49^{* *}$ & $.37^{* *}$ & $.47^{* *}$ \\
\hline \multicolumn{5}{|l|}{ control: cohort groups (Ref: 1960-66) } \\
\hline $1944-49$ & & $3.13^{* *}$ & $3.28^{* *}$ & $3.32^{* *}$ \\
\hline $1950-54$ & & $2.22^{*}$ & $2.16+$ & $2.32^{*}$ \\
\hline $1955-59$ & & 1.39 & 1.49 & 1.39 \\
\hline \multicolumn{5}{|c|}{ educational level (Ref: middle secondary education) } \\
\hline no or lower secondary education & & $-2.96^{* *}$ & $-3.18^{* *}$ & $-3.10^{* *}$ \\
\hline upper secondary education & & 1.70 & 1.44 & 1.52 \\
\hline tertiary education & & $5.09^{* *}$ & $4.72^{* *}$ & $4.50^{* *}$ \\
\hline \multicolumn{5}{|l|}{$\begin{array}{l}\text { interaction effects } \\
\text { prestige at career entry* }\end{array}$} \\
\hline no or lower secondary education & & & .17 & \\
\hline upper secondary education & & & .17 & \\
\hline tertiary education & & & .21 & \\
\hline \multicolumn{5}{|l|}{ prestige at career entry ${ }^{*}$} \\
\hline \multicolumn{5}{|l|}{ prestige development before the first birth* } \\
\hline no or lower secondary education & & & & $-.02^{*}$ \\
\hline upper secondary education & & & & -.01 \\
\hline tertiary education & & & & $-.01^{* *}$ \\
\hline constant & $-.68+$ & $-1.86^{\star *}$ & $-1.71^{*}$ & $-1.85^{\star *}$ \\
\hline $\mathrm{N}$ & 570 & 570 & 570 & 570 \\
\hline $\mathrm{R}^{2}$ & .321 & .362 & .366 & .367 \\
\hline
\end{tabular}

Note: $+\mathrm{p}<.10, * \mathrm{p}<.05, * * \mathrm{p}<.01$ 


\section{The general and education-specific effect of timing and spacing on women's careers}

Since the pending research question is very complex in nature, we divide the analysis of the effect of women's birth behavior and the underlying education-specific effects into three separate, yet interwoven parts. Firstly, we focus on the effect of women's timing and spacing on their career and the underlying effect of the associated activities they participate in. In a second step, we set our focus on education-specific differences between the effects of women's timing and spacing decisions on their careers. At last, we abstractly simulate ideal type courses of female careers by applying the results established before in order to clarify and illustrate the interaction of timing, spacing and the related activities on the one hand and the educational effects on the other hand.

Timing, spacing, and the activities in-between

In the following, we focus on the effect of women's birth behavior and the activities related to it on their career. In Table 6, we gradually integrate variables that measure the timing starting with career entry -, the spacing as well as the associated activities into the main model established before, keeping developments before the timing and general educational expectancies constant. We start off with assessing the - potentially non-linear - effect of the timing in Model 1 as well as the respective effect of the spacing in Model 2. We assumed an inversely $\mathrm{u}$-shaped effect of the timing as well as a profitable prolongation of the spacing for women's careers. For neither of the two measures, however, there is any straightforward evidence for a duration-dependent effect. Apparently, above what women have achieved in terms of prestige, neither the timing of the first births nor the spacing of the second yield an effect on a mother's career. For the timing, it seems reasonable that this effect falls short of revealing underlying educational differences for which we test in a subsequent step. Women's activities before the transition to motherhood, in contrast, predominantly encompass their employment: only rather few women spend some (short) time outside the labor market at all (cf. section 3). Hence, the data does not seem to leave room for activity-specific differences of the timing's impact. For the spacing, however - considering the West German institutional and normative framework which facilitates several years of unpaid caregiving we assume an underlying effect of women's activities between births.

To follow up the assumption regarding the activities during birth spacing and to review our argumentation of an activity-unspecific timing, we test for effects of women's activities in Models 3 to 7. Model 3 shows that, as expected, women's employment prior to family formation does not alter the timing's effect on their career. As by far most women spend their time before family formation in employment, this is not surprising. With regard to the spacing, it seemed theoretically reasonable to space births widely in order to intermit the associated episodes of unpaid caregiving with periods of employment. However, since the West German framework encourages mothers to stay at home for several years, the positive effect of a wide spacing could be blighted by this arrangement. To examine this ambiguity, Models 4 and 5 first assess the effects of the general activities during spacing, without controlling for the duration of women's participation in these activities. We contrast mothers that spend their time between births with unpaid caregiving to those that choose to pursue an employment. As Model 4 suggests, there is no significant effect of generally participat- 
ing in either of those activities. Regarding the respective group of activities by the spacing's duration, however, Model 5 adds valuably to that picture. It reveals that a very small spacing - the conditional main effects ${ }^{21}$ are estimated for the solely analytical spacing of zero years - proves to be much less detrimental if it is spent with unpaid caregiving exclusively. This effect is declining steeply, however, lowering the expectable prestige at 45 by at least one and a third points every year women spend outside the labor market without giving birth to a second child. For some years, participating in an employment between births seems to be even more harmful to a career. It is only after two and a half years that the strong interaction effect of employment and spacing suggests that the penalizing impact of a prolonged spacing can be suspended - although not reversed - by re-entering the labor market. If women space their births beyond that duration, an employment can help to keep the second child penalty to a minimum at about minus three to four prestige points at age 45 . The results suggest that the effect of the spacing is indeed dependent upon women's activities between births: contrary to our assumption, a short spacing in unpaid caregiving seems to be the most profitable arrangement. Spacing births widely and intermitting them with an employment, however, appears to secure some of women's prestige if they decide for a spacing that is longer than two to three years.

To get a deeper understanding of the processes, particularly with regard to women's occupational commitment in full- or part-time employments between births, we assess the more specific duration effects of these activities in Models 6 and 7. As Model 6 shows, there is no significant effect for the duration of any activity during the birth spacing in general: the effect of working full-time or part-time for, e.g., one year between births is not the same during a short and a long spacing. It is, again, only the specific employment in relation to the spacing's duration that proves influential (Model 7). Despite the significant interaction effects for the births' spacing and women's employment variables themselves ${ }^{22}$, there are two other aspects that command attention upon integrating the terms. Firstly, the spacing's squared effect gains considerably in strength and is not far from the defined limit of significance anymore ${ }^{23}$. This suggests that the observed effects lose in intensity across time. Secondly, the conditional main effect of a full-time employment's duration does not vary significantly from the main spacing effect that reflects periods of unpaid caregiving. In combination with a fairly weak positive interaction effect, this suggests that during a spacing's first years it is rather indifferent whether women return to the labor market full-time or if they stay at home to care for the child. Apparently, a full-time employment only proves beneficial after several years of postponing the second child. The respective main effect of a part-time employment's duration, in contrast, falls considerably, outlining a remarkable negative effect of working at short hours. This effect is particularly strong if women return part-time soon after the first births. Then, according to the comparatively weak interaction effect, these detriments balance only after several years.

21 The conditional main effect of an employment during spacing is close to significance at $\mathrm{p}=.12$.

22 The interaction effect of spacing and full-time employment is at $p=.101$.

$23 \mathrm{p}=.13$ 
Table 6: impact of timing, spacing, and the related activities on prestige at age 45

\begin{tabular}{|c|c|c|c|c|c|c|c|}
\hline & $b^{1}$ & $b^{2}$ & $b^{3}$ & $b^{4}$ & $b^{5}$ & $b^{6}$ & $b^{7}$ \\
\hline prestige at career entry & $-.41^{* *}$ & $-.42^{* *}$ & $-.42^{\star *}$ & $-.42^{\star *}$ & $-.43^{* *}$ & $-.41^{* *}$ & $-.41^{* *}$ \\
\hline prestige development before the first birth & $.49^{\star *}$ & $.48^{* *}$ & $.50^{\star *}$ & $.50^{* *}$ & $.49^{* *}$ & $.50^{\star *}$ & $.50^{* *}$ \\
\hline \multicolumn{8}{|l|}{ control: cohort groups (Ref: 1960-66) } \\
\hline $1944-49$ & $3.16^{* *}$ & $3.22^{* *}$ & $3.46^{\star *}$ & $3.51^{* *}$ & $3.48^{\star *}$ & $3.43^{* *}$ & $3.28^{* *}$ \\
\hline $1950-54$ & $2.24^{*}$ & $2.46^{*}$ & $2.87^{\star}$ & $2.87^{*}$ & $3.09^{* *}$ & $2.82^{*}$ & $2.71^{*}$ \\
\hline $1955-59$ & 1.41 & 1.51 & 1.59 & 1.54 & 1.54 & 1.48 & 1.40 \\
\hline \multicolumn{8}{|c|}{ educational level (Ref: middle secondary education) } \\
\hline no or lower secondary education & $-2.95^{\star *}$ & $-2.90^{* *}$ & $-3.00^{* *}$ & $-2.97^{* *}$ & $-2.68^{* *}$ & $-2.91^{* *}$ & $-2.92^{* *}$ \\
\hline upper secondary education & 1.75 & 1.66 & 1.48 & 1.58 & 1.70 & 1.47 & 1.42 \\
\hline tertiary education & $5.18^{* *}$ & $4.98^{* *}$ & $5.33^{* *}$ & $5.29^{* *}$ & $5.51^{* *}$ & $5.26^{* *}$ & $5.22^{* *}$ \\
\hline timing & .26 & .18 & .13 & .14 & .19 & .22 & .23 \\
\hline squared timing & -.02 & -.01 & -.01 & -.01 & -.01 & -.01 & -.01 \\
\hline spacing & & -.44 & -.49 & -.58 & $-1.33^{*}$ & -.64 & -.14 \\
\hline squared spacing & & .01 & .01 & .01 & -.02 & .01 & -.08 \\
\hline \multicolumn{8}{|c|}{ duration of activities before the first birth (ref: employment) } \\
\hline education & & & -.59 & -.56 & -.53 & $-.65+$ & $-.64+$ \\
\hline unemployment & & & $3.94+$ & 3.72 & 3.78 & $4.39+$ & $4.22+$ \\
\hline unpaid caregiving & & & -1.06 & -1.02 & -.89 & -.94 & -.93 \\
\hline other & & & -.49 & -.50 & -.63 & -.58 & -.63 \\
\hline \multicolumn{8}{|c|}{ group of activities during spacing (ref: unpaid caregiving exclusively) } \\
\hline employment & & & & .96 & -3.17 & & \\
\hline other activities & & & & 1.85 & 1.96 & & \\
\hline \multicolumn{8}{|l|}{ interaction effects } \\
\hline employment ${ }^{\star}$ spacing & & & & & $1.33^{*}$ & & \\
\hline \multicolumn{8}{|c|}{ duration of activities during spacing (ref: unpaid caregiving) } \\
\hline education & & & & & & 1.72 & 1.82 \\
\hline unemployment & & & & & & -.35 & -.35 \\
\hline other & & & & & & -.54 & -.65 \\
\hline full-time employment & & & & & & .27 & -.26 \\
\hline part-time employment & & & & & & .13 & $-1.22+$ \\
\hline other/flexible employment & & & & & & .19 & .49 \\
\hline \multicolumn{8}{|l|}{$\begin{array}{l}\text { interaction effects } \\
\text { spacing }^{*}\end{array}$} \\
\hline duration of full-time employment & & & & & & & .10 \\
\hline duration of part-time employment & & & & & & & $.21^{* *}$ \\
\hline constant & $-2.74+$ & -.84 & -.90 & -1.35 & .84 & -.96 & -1.14 \\
\hline $\mathrm{N}$ & 570 & 570 & 570 & 570 & 570 & 570 & 570 \\
\hline $\mathrm{R}^{2}$ & .362 & .368 & .378 & .380 & .387 & .382 & .388 \\
\hline
\end{tabular}

Note: $+\mathrm{p}<.10, * \mathrm{p}<.05,{ }^{* *} \mathrm{p}<.01$

Disconcertingly, these results imply that a (part-time) employment between births can be much less positive for a career than interrupting the participation in the labor market altogether. This relationship contrasts any assumptions that suggest a benefit from occupational commitment and continuity. Presumably, the particularly negative effect of a quick parttime return reflects a specific behavior and decision-making process that has already been 
observed in previous research (Engelbrech 1997; Hirschle 2011): mothers that decide ${ }^{24}$ to return part-time enter a specific track which they follow for a substantial time. Although this track often enables a high flexibility and compatibility of career and family, these benefits apparently come at enormous long-term costs. Not even a full-time return soon after the first birth seems to signal occupational commitment in an outstanding way. Possibly, both effects are a result of women's institutionally and normatively encouraged multi-year parental leave that is typical for the West German conservative regime: even those women that are highly occupationally oriented withdraw from the labor market for about three years and return strongly committed afterwards. Therefore, the signals a full-time employment soon after the first birth sends and the continuity it facilitates are not inherent to occupationally ambitious women. A committed return after a period of unpaid caregiving can have the same effect - which is why we cannot observe a remarkable difference in the data.

\section{Education-specific effects of timing and spacing}

In order to follow up the question how timing and spacing effects vary by educational level, in Table 7 we enter interaction terms of educational level and the respective birth behavior into the model established before. Our assumptions suggest that higher educated women profit stronger from their timing and spacing behavior, because they take their decisions more thoughtfully due to their high opportunity costs and greater reflexivity.

In Model 1, we first assess education-specific effects of the first births' timing. Even though women with middle and upper secondary education have proven to be very similar in their influential factors for a career so far, it is only the latter that benefit substantially from postponing their family formation. The result suggests that these women, who have not fully exhausted their high educational potential in the tertiary sector, make up for this omission on the job. Hence, they seem to have some necessity to establish in the labor market before forming a family in order to make a career.

Beyond that, the integration of the interaction terms also yields that the tertiary education's formerly very positive main effect becomes insignificant conditionally. This result suggests that a timing right after career entry would nullify their high education's positive impact on their career. Apparently, their timing is of major relevance and contributes substantially to their occupational success. Although a precise indication of the educational group's specific timing cannot be derived from the results, highly educated women seem to manage to time their first births individually in a way that is occupationally very beneficial. This interpretation gives some hints to confirming our assumption of a more positive timing effect for highly educated women.

24 That decision could be driven by either a deliberate job change or by some involuntarily necessity due to not finding an access back into one's initial profession - which might urge women to bridge with minor or even marginal employments. 
Table 7: impact of education-specific timing and spacing on prestige at age 45

\begin{tabular}{|c|c|c|}
\hline & 1 & 2 \\
\hline & b & b \\
\hline prestige at career entry & $-.41^{\star *}$ & $-.42^{* *}$ \\
\hline prestige development before the first birth & $.50^{* *}$ & $.49^{* *}$ \\
\hline \multicolumn{3}{|l|}{ control: cohort groups (Ref: 1960-66) } \\
\hline $1944-49$ & $3.27^{\star \star}$ & $3.38^{* *}$ \\
\hline $1950-54$ & $2.71^{*}$ & $2.62^{*}$ \\
\hline $1955-59$ & 1.42 & 1.48 \\
\hline \multicolumn{3}{|l|}{ educational level (Ref: middle secondary education) } \\
\hline no or lower secondary education & $-4.32^{*}$ & -2.58 \\
\hline upper secondary education & -2.39 & $5.76^{*}$ \\
\hline tertiary education & 3.08 & $10.06^{* *}$ \\
\hline timing & .04 & .25 \\
\hline squared timing & -.01 & -.01 \\
\hline spacing & -.22 & .27 \\
\hline squared spacing & -.07 & $-.10+$ \\
\hline \multicolumn{3}{|c|}{ duration of activities before the first birth (ref: employment) } \\
\hline education & $-.75+$ & $-.73^{*}$ \\
\hline unemployment & $4.44+$ & $4.24+$ \\
\hline unpaid caregiving & -.73 & -.88 \\
\hline other & -.92 & -.47 \\
\hline \multicolumn{3}{|c|}{ duration of activities during spacing (ref: unpaid caregiving) } \\
\hline education & 1.88 & 2.43 \\
\hline unemployment & -.35 & -.38 \\
\hline other & -.55 & -.63 \\
\hline full-time employment & -.23 & -.26 \\
\hline part-time employment & $-1.27+$ & $-1.42^{*}$ \\
\hline other/flexible employment & .50 & .49 \\
\hline \multicolumn{3}{|l|}{$\begin{array}{l}\text { interaction effects } \\
\text { spacing* }^{*}\end{array}$} \\
\hline duration of full-time employment & .09 & .09 \\
\hline duration of part-time employment & $.22^{\star *}$ & $.27^{* *}$ \\
\hline \multicolumn{3}{|l|}{ timing* } \\
\hline no or lower secondary education & .20 & \\
\hline upper secondary education & $.56+$ & \\
\hline tertiary education & .32 & \\
\hline \multicolumn{3}{|l|}{ spacing $^{*}$} \\
\hline no or lower secondary education & & -.12 \\
\hline upper secondary education & & $-1.23+$ \\
\hline tertiary education & & $-1.50+$ \\
\hline constant & .35 & -2.48 \\
\hline $\mathrm{N}$ & 570 & 570 \\
\hline $\mathrm{R}^{2}$ & .391 & .395 \\
\hline
\end{tabular}

Note: $+\mathrm{p}<.10,{ }^{*} \mathrm{p}<.05,{ }^{* *} \mathrm{p}<.01$

To follow up the assumption of educationally differing spacing-effects, we insert interaction effects of educational levels and their spacing in Model 2. As a result, the picture becomes even more interesting: pursuing the before complex impact of the spacing and its related activities exposed before, the educational level of women also plays a significant role. In fact, controlling for the interaction uncovers a much more positive conditional 
main effect for all women. Particularly women with at least upper secondary education would profit enormously from a very short spacing, yet every year of postponing the second births proves more detrimental to the expectable prestige at age 45 . Women with low education would be able to make up for some of their disadvantages they have compared to intermediately educated women by spacing their births more shortly. At first glance, this suggests that they forfeit some opportunities by spacing their births the way they do although a spacing of zero years as represented in the data is, of course, impossible.

Drawing upon previous research helps to comprehend that picture. The spacing of highly educated women has been found to be considerably shorter than that of women with no or lower education (e.g. Kreyenfeld 2002). So far, this has been explained by a partner effect and self-selectivity: firstly, their short spacing is due to their higher material security that is provided by their homogamous partner and, secondly, to the higher family orientation they display when they decide in favor of motherhood despite their high opportunity costs. Our results, however, suggest an additional explanation: higher educated women space their two births more closely in order to better seize their occupational opportunities by returning to the labor market more quickly. Since the West German institutional and normative framework somewhat puts obstacles to returning to the labor market soon after the first birth, they instead opt to return as soon as possible after their period of childcare. To keep the resulting interruption of their employment short, they space their births more closely - though they still lose some chances to accumulate prestige through their spacing of about two to three years.

Birth spacing, the related activities and the underlying educational effects

The profoundly examined results of Tables 6 and 7 in the previous sections have already yielded an in-depth impression of the impact exerted by women's particular birth behaviors, the associated activities as well as their educational level on their career development. This picture was shown to be particularly complex for women's spacing between the first and the second births: on the one hand, the spacing's effect was highly dependent upon women's activities between births. While reentering into a part-time employment soon after the first birth has generally turned out to be very detrimental to women's long-term career, participating in unpaid caregiving before having the second child within only a few years has been shown to be the occupationally most beneficial choice. On the other hand, educationspecific results concerning the spacing of births have shown that there are indeed considerable differences between women of various educational groups: particularly highly educated women benefit substantially from a shorter spacing of births.

However, since it is very hard to understand how these different effects of women's activities during their spacing and their education coincide with one another, we aim to add some clarification to this complex picture in the following. Focusing on the youngest cohort, we simulate some of women's ideal type career developments by applying the results established before (Model 2 of Table 7) to abstract compositions of female education, birth behavior, and activities. Drawing upon these ideal type figures, at first we pay attention to the specific effects different spacing behaviors and activities have on women's prestige development between career entry and the age of 45 . Secondly, we illustrate the impact these ideal type behaviors have, realistically, on women's prestige at the age of 
45. To do so, we visualize the effects in relation to the average prestige measures of differently educated women before family formation, precisely their prestige at career entry and their prestige development before their first births. To provide these pictures of the youngest cohort's ideal type birth spacing behaviors and activities by education, we calculate the effects of different spacing durations, exemplarily applying a continuous episode of unpaid caregiving, an employment interruption of six months followed by parttime or full-time employment and a respective interruption of three years.

In Figure 3, we first illustrate the specific effects of the different spacing behaviors and acitivites by educational groups. Since controlling for an education-specific birth spacing (Model 2 of Table 7) has been accounting for differences between women with no or lower and middle secondary education, we summarize these educational groups and hence compare women with no or lower/middle secondary, upper secondary and tertiary education in Figure 3.

Figure 3: effect on career across different activities during spacing, by educational degree

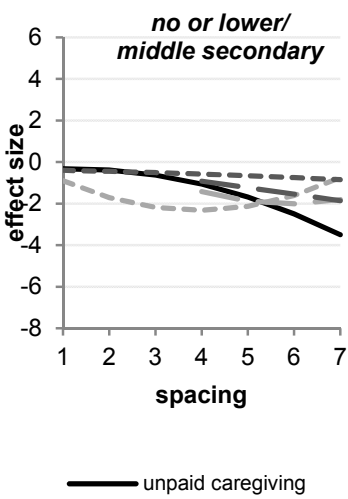

Note: timing constant at seven years.
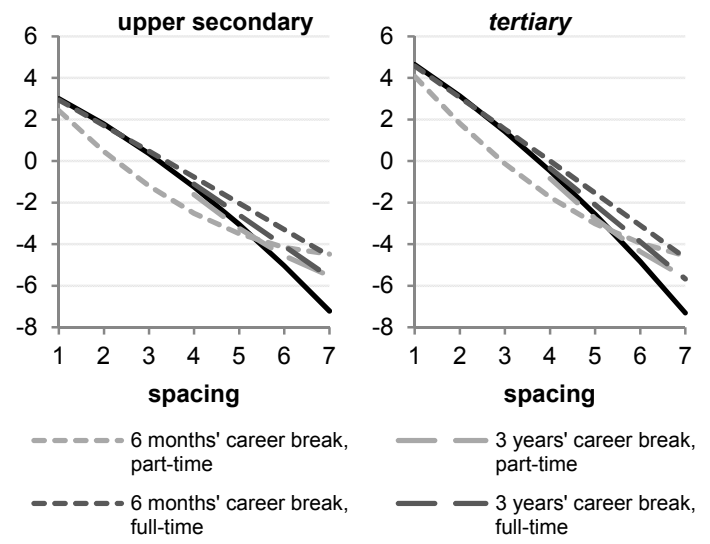

It becomes apparent that there are both major activity-specific and education-specific differences. At first regarding the latter, the graphs impressively demonstrate the enormous career impairments women with at least upper secondary education face with every additional year of postponing the second birth. The activity between births plays, in contrast, a comparatively subordinate part - the most important aspect in order to affect their career is the birth spacing's duration.

Beneath, however, there are still activity-specific differences that are particularly meaningful for mothers with no, lower and middle secondary education. The figure yields that the effects of episodes of unpaid caregiving and full-time employment do not vary considerably from one another during the first three years. It is only after that time that both slopes diverge increasingly and a full-time employment - particularly one that has been entered as soon as half a year after the first birth - proves to be noticeably less detrimental than unpaid caregiving. A part-time employment soon after birth, however, decreases the expectable prestige at age 45 immensely right from the start; the effect even intensifies during the first three to four years. It is only after as much as five years of birth spacing that the slopes 
of unpaid caregiving and part-time employment intersect. This implies that the concerning part-time occupational period starts to become less detrimental for the career than having stayed at home for those five years plus of birth spacing. By that time, however, the effect is of rather theoretical nature as most women will have already given birth to a second child.

Although Figure 3 has already contributed greatly to comprehending the effect of differently educated women's birth spacing behavior and the associated activities, what remains is the central question concerning the all-encompassing impact of these behaviors on women's career developments. Figure 4 helps to clarify the picture by illustrating all educational groups' mean prestige base levels and achievements before timing as well as their long-term progression depending on birth spacing and activity behaviors, again drawing upon exemplary combinations of birth spacings and activities. Specifically, we single out birth spacing behaviors of one or three years, both spent exclusively with unpaid caregiving. For the birth spacing duration of three years, we additionally look into a return into part-time employment after half a year. The impact of any full-time employment, in contrast, has to be neglected as its effect does not differ from that of unpaid caregiving during the exemplarily observed birth spacings of up to three years (cf. Figure 3).

Figure 4: ideal type career development between career entry and age 45 , by educational level and activity during a one and three year spacing

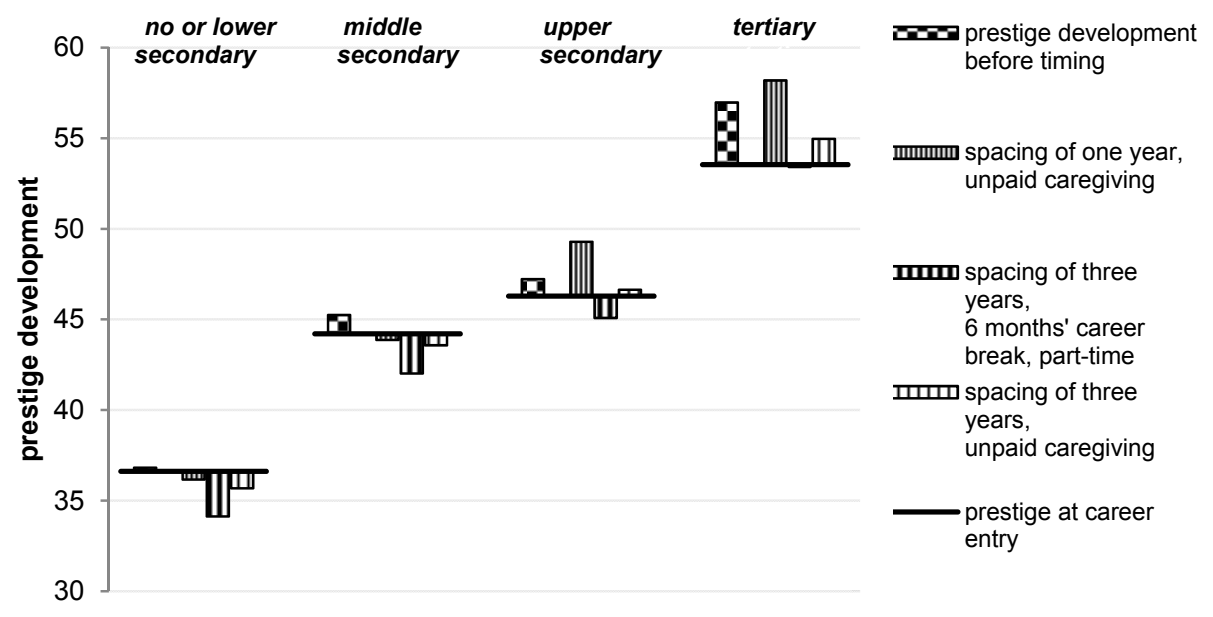

Note: timing constant at seven years.

Particularly for women with intermediate education who, on average, gained noticeably before family formation, Figure 4 shows that the occupational child penalty is strong and not effectively compensable: whatever spacing and activity they choose, the expectable prestige at age 45 falls below the average prestige at career entry. Only higher educated mothers of two seem to have chances of further accumulating prestige between career entry and the age of 45 . However, gaining prestige beyond what they have attained during the most beneficial time before family formation appears to be only possible if they space their two children very shortly. Already a spacing of as little as three years contributes to a loss of prestige compared to what they were able to attain before their first births on av- 
erage. Still, assuming a birth spacing of three years at the maximum, the most diminishing behavior for all educational groups is to participate in a part-time employment soon after the first birth: the expectable prestige at the career's high point at age 45 is far lower than it had been before those women decided for their first child and mostly even below the prestige level they started off with at career entry.

\section{Summary and conclusion}

Although research has already addressed the issue of how women in West Germany reconcile family and career and in what way their family obligations impact their careers (e.g. Engelbrech 1997; Grunow et al. 2006; Matysiak/Steinmetz 2006; Aisenbrey et al. 2009; Gangl/Ziefle 2009; Grunow et al. 2011), what has been underrepresented in the academic debate up to now is if and how women's careers are influenced by the way women embed their birth decisions into their life courses. Precisely, since two children are normatively and empirically prevalent in Germany, this question applies to timing the first birth as well as spacing the second. Hence, the central aim of our study was to understand the impact exerted by these two birth decisions on West German women's long-term careers. Specifically, we reconstructed (1) West German women's career development up to the age of 45 in general as well as before and after first birth and (2) the role of the timing of the first birth and the spacing of the second for women's career development. In both cases, a special focus was placed on the question if and how women's education alters the influences exerted by family formation and birth behavior on their careers.

Regarding women's career developments before and after the first birth, we could show that the period after family formation is firstly unexpectedly influential and secondly highly detrimental to women's careers. Even positive prestige attainments before the first births cannot ensure career stability afterwards. Particularly women with no or lower secondary education face the highest amount of insecurity once they are mothers. Considerable career developments before their first births, however, although being generally rather rare, can influence their long-term career remarkably. Highly educated women, in contrast, can chose from a variety of opportunities before family formation. The prestige drawn from these opportunities depicts a long-term career security beyond their transition to motherhood.

With respect to the impact exerted by the timing of the first births and their spacing of the second on women's careers, the analyses did not yield a general effect of the birth behavior itself. Instead, particularly for the spacing, the activities women participated in between both births have proven to be of major, yet very unexpected relevance: while bridging the births' spacing by exclusively caring for the first child for some years was shown to be the occupationally most rational decision, reentering the labor market part-time soon after the first birth has turned out to be highly detrimental in most cases. A full-time employment, instead, only pays off after participating in the labor market for several years while postponing the second birth. Apparently the West German institutional and normative framework, which encourages mothers to stay at home for several years to care for their children, confounds the positive consequences from labor market continuity and occupational commitment that could be obtained by returning quickly after the first child's 
birth. Additionally, the prestige diminishing effect of a part-time employment suggests the existence of a 'mommy track': even though working part-time often enables mothers to flexibly combine family and career, these benefits apparently come at considerable long-term costs to the career (see also Engelbrech 1997; Hirschle 2011).

Regarding educational differences in the effects wielded by women's birth timing and spacing, it could be shown that education indeed influences the way in which women impact their career through their birth behavior. Firstly, the results suggested that higher educated women are able to time their first births in a way that proves to be beneficial, in terms of prestige, in the long term. Secondly, we found that the overall shorter spacing of highly educated women can be explained by their very high occupational profit from spacing births shortly: while the West German institutional and normative framework discourages returning to the labor market during the first years after the first birth, highly educated women seem to circumvent these obstacles to labor market continuity and commitment by keeping the period of consecutive childcare short. This finding adds valuably to the literature that researches the reasons for higher educated women's short birth spacing (e.g. Kreyenfeld 2002; Bernhard/Kurz 2007). A short spacing of births even gives highly educated women the chance to accumulate prestige beyond the high attainment they achieve before their family formation - while mothers of two children with low education seem to fall beneath their prestige at career entry in any event.

Although answering many open questions, our study also leaves some questions still unanswered to future research. Firstly, since the period after family formation has proven to be very influential and has not been fully explained so far, a closer look particularly at the activities after the consecutive periods of childcare, i.e. women's labor market behavior after their last births, would be worthwhile. Another focal point of interest would be to examine the impacts wielded by birth behavior on long-term career for both East and West German women. Particularly interesting in this regard is a long-term comparison, specifically after German reunification and in the light of the latest changes in paradigm concerning Germany's family policies (e.g. Bujard 2013).

\section{References}

Aisenbrey, S., Evertsson, M. \& Grunow, D. (2009). Is there a career penalty for mother's time out? A comparison of Germany, Sweden and the United States. Social Forces, 88, 2, pp. 573-606.

Arrow, K. (1973). The theory of discrimination. Princeton: Princeton University, Industrial Relations Section (Working paper, 30A).

Bauer, G. \& Jacob, M. (2010). Fertilitätsentscheidungen im Partnerschaftskontext. Kölner Zeitschrift für Soziologie und Sozialpsychologie, 62, 1, pp. 31-60.

Becker, G. S. (1985). Human capital, effort, and the sexual division of labor. Journal of Labor Economics, 3, 1 pt. 2, pp. S33-S58.

Beets, G. (2011). The demography of the age at first birth. The close relationship between having children and postponement. In: Beets, G., Schippers, J. \& te Velde, E. R. (Eds.), The future of motherhood in western societies. Late fertility and its consequences. Dordrecht, New York: Springer, pp. 61-90.

Bernhard, S. \& Kurz, K. (2007). Familie und Arbeitsmarkt. Eine Längsschnittstudie zum Einfluss beruflicher Unsicherheiten auf die Familienerweiterung. Nürnberg: Institut für Arbeitsmarkt- und Berufsforschung (IAB Discussion Paper, 10/2007).

Berninger, I. (2009). Welche familienpolitischen Maßnahmen fördern die Arbeitsmarktpartizipation von Müttern? Kölner Zeitschrift für Soziologie und Sozialpsychologie, 61, 3, pp. 355-385. 
Blossfeld, H.-P. \& Huinink, J. (1991). Human capital investments or norms of role transition? How women's schooling and career Affect the process of family formation. American Journal of Sociology, 97, 1, pp. 143-168.

Blossfeld, H.-P., Roßbach, H.-G. \& Maurice, J.von (2011). Education as a lifelong process. The German National Educational Panel Study (NEPS). Sonderheft 14 der Zeitschrift für Erziehungswissenschaft.

Brehm, U. (2013). Kinder (an) der Zeit. Das Erst- und Zweitgeburtenverhalten ost- und westdeutscher Frauen im Zeitverlauf. Bamberg: Otto-Friedrich-Universität Bamberg (Masterarbeit).

Brose, N. (2008). Entscheidung unter Unsicherheit. Familiengründung und -erweiterung im Erwerbsverlauf. Kölner Zeitschrift für Soziologie und Sozialpsychologie, 60, 1, pp. 34-56.

Buchholz, S. \& Grunow, D. (2006). Women's employment in West Germany. In: Blossfeld, H.-P. \& Hofmeister, H. (Eds.), Globalization, uncertainty and women's careers. An international comparison. Cheltenham, Northampton, Edward Elgar Publishing, pp. 61-83.

Bujard, M. (2013). Die fünf Ziele des Elterngelds im Spannungsfeld von Politik, Medien und Wissenschaft. In: Bujard, M. (Eds.), Schwerpunktthema: Elterngeld und Elternzeit in Deutschland. Ziele, Diskurse und Wirkungen. Zeitschrift für Familienforschung/Journal of Family Research, 2013, 2, pp. 132-153.

DiPrete, T. A. \& Soule, W. T. (1988). Gender and promotion in segmented job ladder systems. American Sociological Review, 53, 1, pp. 26-40.

Drasch, K. (2011). Zwischen familiärer Prägung und institutioneller Steuerung. Familienbedingte Erwerbsunterbrechungen von Frauen in Ost- und Westdeutschland und der DDR. In: Berger, P. A., Hank, K. \& Tölke, A. (Eds.), Reproduktion von Ungleichheit durch Arbeit und Familie. Wiesbaden: VS Verlag für Sozialwissenschaften, pp. 171-200.

Engelbrech, G. (1997). Erziehungsurlaub - und was dann? Die Situation von Frauen bei ihrer Rückkehr auf den Arbeitsmarkt - Ein Ost/West-Vergleich. Nürnberg: Institut für Arbeitsmarkt- und Berufsforschung (IAB-Kurzbericht, 8).

Esping-Andersen, G. (1990). The three worlds of welfare capitalism. Oxford: Polity Press.

Falk, S. \& Schaeper, H. (2001). Erwerbsverläufe von ost- und westdeutschen Müttern im Vergleich. Ein Land - ein Muster? In: Born, C. \& Krüger, H. (Eds.), Individualisierung und Verflechtung. Geschlecht und Generation im deutschen Lebenslaufregime. Weinheim, München: Juventa, pp. 181-210.

Frodermann, C., Müller, D. \& Abraham, M. (2013). Determinanten des Wiedereinstiegs von Müttern in den Arbeitsmarkt in Vollzeit oder Teilzeit. Kölner Zeitschrift für Soziologie und Sozialpsychologie, 65, 4, pp. 645-668.

Gangl, M. \& Ziefle, A. (2009). Motherhood, labor force behavior, and women's careers. An empirical assessment of the wage penalty for motherhood in Britain, Germany, and the United States. Demography, 46, 2, pp. 341-369.

Goldstein, J. R. \& Kreyenfeld, M. (2010). East Germany overtakes West Germany. Recent trends in order-specific fertility dynamics. Rostock: Max-Planck-Institut für demografische Forschung (MPIDR Working Paper, 2010-033).

Grunow, D. (2006). Convergence, persistence and diversity in male and female careers: Does context matter in an era of globalization? A comparison of gendered employment mobility patterns in West Germany and Denmark. Opladen, Farmington Hills: Barbara Budrich.

Grunow, D., Aisenbrey, S. \& Evertsson, M. (2011). Familienpolitik, Bildung und Berufskarrieren von Müttern in Deutschland, USA und Schweden. Kölner Zeitschrift für Soziologie und Sozialpsychologie, 63, 3, pp. 395-430.

Grunow, D., Hofmeister, H. \& Buchholz, S. (2006). Late 20th-century persistence and decline of the female homemaker in Germany and the United States. International Sociology, 21, 1, pp. 101131.

Grunow, D. \& Müller, D. (2012). Kulturelle und strukturelle Faktoren bei der Rückkehr in den Beruf. Ostdeutsche, westdeutsche und ost-west-mobile Mütter im Vergleich. In: Huinink, J., Kreyenfeld, M. \& Trappe, H. (Eds.), Familie und Partnerschaft in Ost- und Westdeutschland. Ähnlich und doch immer noch anders. Opladen, Berlin, Toronto: Barbara Budrich (Sonderheft 9 der Zeitschrift für Familienforschung/Journal of Family Research), pp. 55-77. 
Grunow, D., Schulz, F. \& Blossfeld, H.-P. (2007). Was erklärt die Traditionalisierungsprozesse häuslicher Arbeitsteilung im Eheverlauf. Soziale Normen oder ökonomische Ressourcen. Zeitschrift für Soziologie, 36, 3, pp. 162-181.

Gustafsson, S. (2001). Optimal age at motherhood. Theoretical and empirical considerations on postponement of maternity in Europe. Journal of Population Economics, 14, 2, pp. 225-247.

Hanel, B. \& Riphahn, R. T. (2011). The employment of young mothers after birth. Recent developments and their determinants in East and West Germany. Bonn: Forschungsinstitut zur Zukunft der Arbeit (IZA DP, 5752).

Hipp, L. \& Stuth, S. (2013). Management und Teilzeit? Eine empirische Analyse zur Verbreitung von Teilzeitarbeit unter Managerinnen und Managern in Europa. Kölner Zeitschrift für Soziologie und Sozialpsychologie, 65, 1, pp. 101-128.

Hirschle, J. (2011). Familie, Geschlecht und Klassenmobilität. Der Einfluss der Geburt eines Kindes auf die Berufskarrieren von Frauen und Männern. Arbeit, 20, 2, pp. 112-126.

Institut für Arbeit und Qualifikation (2014). Besuchsquoten in Tageseinrichtungen nach Altern der Kinder 2013. http://www.sozialpolitik-aktuell.de/tl_files/sozialpolitik-aktuell/_Politikfelder/Familienpolitik/ Datensammlung/PDF-Dateien/abbVII21.pdf [Retrieved: 2014-05-12].

Karimi, A. (2014a). Birth spacing and women's subsequent earnings. Evidence from a natural experiment. In: Karimi, A. (Ed.), Impacts of policies, peers and parenthood on labor market outcomes. Uppsala: Uppsala Universitet,, Nationalekonomiska Institutionen, pp. 69-103.

Karimi, A. (2014b). The effect of fertility timing on career outcomes. Evidence from biological fertility shocks. In: Karimi, A. (Ed.), Impacts of policies, peers and parenthood on labor market outcomes. Uppsala: Uppsala Universitet, Nationalekonomiska Institutionen, pp. 21-68.

Kreyenfeld, M. (2002). Time squeeze, partner effect or self-selection? Demographic Research, 7, pp. 15-48.

Kreyenfeld, M. (2007). Bildungsspezifische Unterschiede im Geburtenverhalten in Ost- und Westdeutschland. In: Barlösius, E. \& Schiek, D. (Eds.), Demographisierung des Gesellschaftlichen. Analysen und Debatten zur demographischen Zukunft Deutschlands. Wiesbaden: VS Verlag für Sozialwissenschaften, pp. 83-112.

Lauterbach, W. (1994). Berufsverläufe von Frauen. Erwerbstätigkeit, Unterbrechung und Wiedereintritt. Frankfurt am Main: Campus.

Lazear, E. P. \& Rosen, S. (1990). Male-female wage differentials in job ladders. Journal of Labor Economics, 8, 1, Part 2: Essays in Honor of Albert Rees, pp. S106-S123.

Matysiak, A. \& Steinmetz, S. (2006). Who follows whom? Female employment patterns in West Germany, East Germany and Poland. Mannheim: Mannheimer Zentrum für Europäische Sozialforschung (Working Papers, 94).

Mayer, K. U. (1991). Soziale Ungleichheit und die Differenzierung von Lebensverläufen. In: Zapf, W. (Ed.), Die Modernisierung moderner Gesellschaften. Frankfurt am Main: Campus, pp. 667-687.

Miller, A. R. (2011). The effects of motherhood timing on career path. Journal of Population Economics, 24, 3, pp. 1071-1100.

Miller, C. F. \& Xiao, J. J. (1999). Effects of birth spacing and timing on mothers' labor force participation. Atlantic Economic Journal, 27, 4, pp. 410-421.

Newman, J. L. (1983). Economic analyses of the spacing of births. The American Economic Review, 73, 2, pp. 33-37.

Ochsenfeld, F. (2012). Gläserne Decke oder goldener Käfig. Scheitert der Aufstieg von Frauen in erste Managementpositionen an betrieblicher Diskriminierung oder an familiären Pflichten? Kölner Zeitschrift für Soziologie und Sozialpsychologie, 64, 3, pp. 507-534.

Pema, E. \& Mehay, S. (2010). The role of job assignment and human capital endowments in explaining gender differences in job performance and promotion. Labour Economics, 17, 6, pp. 998-1009.

Pfau-Effinger, B. (1996). Analyse internationaler Differenzen in der Erwerbsbeteiligung von Frauen. Theoretischer Rahmen und empirische Ergebnisse. Kölner Zeitschrift für Soziologie und Sozialpsychologie, 48, 3, pp. 462-492.

Pfau-Effinger, B. \& Smidt, M. (2011). Differences in women's employment patterns and family policies. Eastern and Western Germany. Community, Work \& Family, 14, 2, pp. 217-232. 
Phelps, E. S. (1972). The statistical theory of racism and sexism. The American Economic Review, 62, 4, pp. 659-661.

Putz, T. \& Engelhardt, H. (2014, in this volume). The effects of the first birth timing on women's wages. A longitudinal analysis based on the German Socio-economic Panel. Zeitschrift für Familienforschung/Journal of Family Research,2014, 3, pp. 302-330.

Reichle, B. (1996). Der Traditionalisierungseffect beim Übergang zur Elternschaft. Zeitschrift für Frauenforschung, 14, 4, pp. 70-89.

Rosenfeld, R. A., Trappe, H. \& Gornick, J. C. (2004). Gender and work in Germany. Before and after reunification. Annual Review of Sociology, 30, 1, pp. 103-124.

Schippers, J. (2011). The economic rationality of late parenthood. In: Beets, G., Schippers, J. \& te Velde, E. R. (Eds.), The future of motherhood in western societies. Late fertility and its consequences. Dordrecht, New York: Springer, pp. 91-105.

Schulz, F. \& Blossfeld, H.-P. (2006). Wie verändert sich die häusliche Arbeitsteilung im Eheverlauf? Eine Längsschnittstudie der ersten 14 Ehejahre in Westdeutschland. Kölner Zeitschrift für Soziologie und Sozialpsychologie, 58, 1, pp. 23-49.

Spilerman, S. \& Petersen, T. (1999). Organizational structure, determinants of promotion, and gender differences in attainment. Social Science Research, 28, pp. 203-227.

Timm, A. (2006). Die Veränderung des Heirats- und Fertilitätsverhaltens im Zuge der Bildungsexpansion. Eine Längsschnittanalyse für West- und Ostdeutschland. In: Hadjar, A. \& Becker, R. (Eds.), Die Bildungsexpansion. Erwartete und unerwartete Folgen. Wiesbaden: VS Verlag für Sozialwissenschaften, pp. 277-309.

Treiman, D. J. (1975). Problems of concept and measurement in the comparative study of occupational mobility. Social Science Research, 4, 3, pp. 183-230.

Troske, K. R. \& Voicu, A. (2009). The effect of the timing and spacing of births on the level of labor market involvement of married women. Bonn: Forschungsinstitut zur Zukunft der Arbeit (IZA DP, 4417).

Vogel, C. (2009). Teilzeitbeschäftigung. Ausmaß und Bestimmungsgründe der Erwerbsübergänge von Frauen. Zeitschrift für Arbeitsmarktforschung, 42, 2, pp. 170-181.

Weber, A. M. (2004). Wann kehren junge Mütter auf den Arbeitsmarkt zurück? Eine Verweildaueranalyse für Deutschland. Mannheim: Zentrum für Europäische Wirtschaftsforschung (ZEW Discussion Papers, 04-08).

Ziefle, A. (2004). Die individuellen Kosten des Erziehungsurlaubs. Eine empirische Analyse der kurzund längerfristigen Folgen für den Karriereverlauf von Frauen. Kölner Zeitschrift für Soziologie und Sozialpsychologie, 56, 2, pp. 213-231.

Submitted on/Eingereicht am: 20.05.2014

Accepted on/Angenommen am: 22.10.2014

Addresses of the authors/Anschriften der Autorinnen:

Uta Brehm, M.A. (Corresponding author/Korrespondenzautorin)

Bamberg Graduate School of Social Sciences (BAGSS)

Prof. Dr. Sandra Buchholz

Lehrstuhl für Soziologie I

Otto-Friedrich-Universität Bamberg

Feldkirchenstraße 21

96052 Bamberg

Germany/Deutschland

E-Mail: uta.brehm@uni-bamberg.de sandra.buchholz@uni-bamberg.de 